\title{
Polyphase scheelite and stanniferous silicates in a W-(Sn) skarn close to Felbertal tungsten mine, Eastern Alps
}

\author{
Alexander Ordosch ${ }^{1,2}$ (Dohann G. Raith ${ }^{1} \cdot$ Steffen Schmidt ${ }^{3} \cdot$ Karsten Aupers $^{3}$
}

Received: 9 June 2018 / Accepted: 12 June 2019 /Published online: 6 July 2019

(C) The Author(s) 2019

\begin{abstract}
The scheelite exploration target Messelingscharte (Eastern Tyrol, Austria) is located in vicinity of the world-class Felbertal tungsten deposit. W-(Sn) mineralisation occurs in Early Palaeozoic amphibolites (Basal Amphibolite unit) in the Tauern Window of the Eastern Alps. The most important mineralisation type is a Sn-bearing clinozoisite-scheelite skarn of preAlpine (Variscan?) age. It occurs as metre-sized irregular pods within amphibolites and amphibole schists. It is composed of major clinozoisite, quartz, plagioclase and scheelite with minor and accessory titanite, calcite and chlorite. Bulk chemical analyses reveal high concentrations of the granitophile elements $\mathrm{W}\left(\leq 7.74 \mathrm{wt} \% \mathrm{WO}_{3}\right), \mathrm{Sn}\left(\leq 1254 \mathrm{ppm} \mathrm{SnO}_{2}\right), \mathrm{Be}(\leq 41 \mathrm{ppm})$ and base metals $\left(\mathrm{Cu}, \mathrm{Pb}, \mathrm{Zn} ; \sum \leq 2500 \mathrm{ppm}\right)$ in the skarn rock. Three scheelite types are distinguished based on micro-textures, zoning, Mo-content and UV- fluorescence. They show intriguing similarities to scheelite from the Felbertal tungsten deposit where pre-Alpine Mo-bearing scheelite was apparently overprinted by two stages of metamorphism. The unique feature of the investigated W-(Sn) skarn is the association of scheelite with Sn-bearing silicates. Stanniferous clinozoisite and stanniferous titanite were identified as the main $\mathrm{Sn}$ carriers (clinozoisite $\leq 3.00 \mathrm{wt} \% \mathrm{SnO}_{2}$; titanite $\leq 6.48 \mathrm{wt} \% \mathrm{SnO}_{2}$ ); both minerals evidence metamorphic re-crystallisation. Substitution of $(\mathrm{Al}, \mathrm{Fe})^{3+}$ by $(\mathrm{Sn}, \mathrm{Ti})^{4+}$ in clinozoisite is coupled with incorporation of $\mathrm{Fe}^{2+}$. The skarn formed by interaction of fluids of likely magmatic-hydrothermal origin with metabasites. The clinozoisite-dominated calcsilicate rocks are interpreted as a metamorphosed distal W-(Sn) skarn.
\end{abstract}

Keywords Tungsten-tin skarn $\cdot$ Scheelite $\cdot$ Stanniferous clinozoisite $\cdot$ Tauern Window $\cdot$ Eastern Alps

\section{Introduction}

A multitude of scheelite occurrences were discovered in the 1960s to 1980s in the Eastern Alps including the Felbertal scheelite deposit, which nowadays is one of the largest tungsten producers outside China (annual production $20161200 \mathrm{t}$ $\mathrm{WO}_{3}$ ). This exceptional deposit is hosted in Early Palaeozoic metamorphic sequences, mainly in metabasites of the central

Editorial handling: A. R. Chakhmouradian

Alexander Ordosch

alexander.ordosch@icloud.com

1 Chair of Resource Mineralogy, Montanuniversität Leoben, Peter-Tunner Straße 5, 8700 Leoben, Austria

2 Present address: Watersmeet Place, Green Lanes, London, UK

3 Wolfram Bergbau und Hütten AG, Bergla 33, 8543 St. Martin i.S, Austria
Tauern Window, which were intruded by numerous granites during the Variscan orogeny ( $\sim 340-290 \mathrm{Ma}$ ) and subsequently metamorphosed during the Alpine orogeny ( $\sim 30 \mathrm{Ma})$. Since its discovery in 1967, the ideas on the genesis of Felbertal changed dramatically. Whereas in the early days the deposit was interpreted as a syngenetic stratiform / strata-bound scheelite deposit (Höll 1975) there is now convincing evidence that it is related to c. 340 Ma Variscan granites (Kozlik et al. 2016; Raith et al. 2011; Raith and Stein 2006).

In 2015, Wolfram Bergbau und Hütten AG (WBH AG), the company operating the Felbertal mine, decided to re-explore scheelite showings at Messelingscharte (located about $8 \mathrm{~km}$ to the south of Felbertal) in the course of a regional exploration program. Messelingscharte was initially discovered in the 1960s and explored in the 1970s but after the discovery of Felbertal, it was never explored and studied in detail. As shown in this paper the main mineralisation is a Sn-bearing scheelite skarn, which was not identified correctly in the 1960s. The particular feature is that $\mathrm{Sn}$ is hosted in Casilicates and not in cassiterite. 
This study presents mineralogical data on scheelite and stanniferous silicates together with bulk geochemical data. It will be demonstrated that the mineralisation at Messelingscharte is unique in the Eastern Alps and cannot be compared with other known scheelite occurrences in the region. Mineralised systems containing $\mathrm{Sn}$ in addition to $\mathrm{W}$ are extremely rare in the Eastern Alps; e.g., only traces of Sn are found in the Felbertal deposit and Sn is lacking in all other scheelite occurrences in the Eastern Alps. Stanniferous silicates are known from magmatic skarn deposits, but there are very few comparable examples to Messelingscharte documented in the international literature.

\section{Geological setting}

The study area is located in the central Tauern Window in the Eastern Alps (Fig. 1) where the pre-Alpine European basement with its Late Carboniferous to Mesozoic sedimentary cover and Penninic oceanic units is exposed over an area of about $6500 \mathrm{~km}^{2}$. The rocks comprise metamorphosed Cambro-Ordovician basement units, Permo-Carboniferous granite intrusions and post-Variscan cover units derived from the distal European margin (Subpenninic units) as well as Mesozoic allochthonous Penninic units from the Penninic ocean and Austroalpine units (Schmid et al. 2013). A prominent tectonic feature in the Tauern Window is the Venediger Duplex, a folded stack of several tectonic nappes formed during the subduction and collision stage of the Alpine orogeny (Frisch 1977; Lammerer and Weger 1998; Schmid et al. 2013).

In the central Tauern Window, several Variscan metagranitoids (e.g., Granatspitz gneiss, Felbertauern augengneiss), pre-Variscan to Variscan metamorphic units (Basal Amphibolite, Habach Complex), as well as postVariscan Permo-Mesozoic cover and oceanic sequences are exposed (Fig. 1). They all belong to the Subpenninic and Penninic units of the Eastern Alps (Schmid et al. 2004, 2013). The Granatspitz Gneiss is a peraluminous S-type meta-granite forming a dome structure (Fig. 1) with an area of $\sim 100 \mathrm{~km}^{2}$. Ages of $314 \pm 1 \mathrm{Ma}$ (Kebede et al. 2005), $314 \pm$ $18 \mathrm{Ma}$ (Kozlik et al. 2016), and even as young as $271 \pm 4 \mathrm{Ma}$ (Eichhorn et al. 2000) have been reported for this metagranite. The former intrusive contact with the overlying Basal Amphibolite unit is largely tectonically reworked (Frank 1969).

The Basal Amphibolite (Basisamphibolit) unit comprises banded amphibolites and meta-gabbros showing (enriched) MORB-like geochemical signatures typical of back-arc magmas (Frisch and Raab 1987; Vavra and Frisch 1989; Höck 1993; Ordosch 2017). The protolith age is debated; conventional $\mathrm{U}-\mathrm{Pb}$ zircon ages of $657+14 /-15 \mathrm{Ma}$ and a Sm-Nd age of $664 \pm 12 \mathrm{Ma}$ were reported for a banded amphibolite (von Quadt 1992); a metagabbro yielded a U-Pb zircon age of $539+10 /-9 \mathrm{Ma}$, which roughly coincides with the U-Pb SHRIMP age of $551 \pm 9$ Ma reported for a hornblendeplagioclase gneiss (Eichhorn et al. 2001). In contrast, Kebede et al. (2005) published much younger in situ U-Pb zircon ages of 351-343 Ma for the Basal Amphibolite and therefore grouped it with the Variscan basement series in the Tauern Window. In this paper, it is assigned to the preVariscan basement units (Fig. 1). The overlying metavolcano-sedimentary sequence is referred to as the Basal Schist (Basisschiefer; synonymous Eiser sequence); it forms the basal unit of the Habach Complex (Höck 1993). The Basal Schist unit includes metasediments (micaschist, paragneiss, graphitic quartzite, metaconglomerate) and mafic to felsic metavolcanics, possibly formed in a continental arc setting (Fuchs 1959; Pestal et al. 2009; Schuster et al. 2006). Detrital zircons from the Basal Schist yielded an U-Pb age of $362 \pm 6 \mathrm{Ma}$ (Kebede et al. 2005) and it has therefore been reinterpreted as a Lower Carboniferous metamorphosed flysch sequence (Draxel Complex, Pestal et al. 2009; Schuster et al. 2006).

The Habach Complex represents the largest area of PreMesozoic volcano-sedimentary basement rocks in the central Tauern Window (Frasl 1958; Höll 1975; Höck 1993). In the area around Messelingscharte it is in tectonic contact with the underlying Basal Amphibolite; further to the north (e.g., at the Felbertal scheelite mine) its base is formed by the Basal Schist. There, the contact was interpreted controversially; either as unconformable sedimentary (e.g., Höck 1993) or tectonic, i.e., as a major Alpine thrust fault (Höll and Eichhorn 2000).

The poly-metamorphic Habach Complex consists of various pre-Variscan meta-igneous rocks, clastic metasediments and Variscan meta-granitoids (Eichhorn et al. 2001; Höck 1993). It is subdivided (from bottom to top) into the Lower Magmatic Series, Upper Magmatic Series and the Habach Phyllite (Fig. 1; Höck 1993; Höll 1975; Höll and Eichhorn 2000; Kraiger 1989; Pestal et al. 2009). The Lower Magmatic Series is a dismembered meta-ophiolite; it consists of amphibolites, metagabbros, meta-ultramafic rocks (hornblendite, serpentinite) and minor metasediments of Cambrian to Ordovician age. Felsic orthogneisses within this sequence derived from Early Cambrian I-type granitoids (Eichhorn et al. 1995). Moreover, it hosts the world-class Felbertal tungsten deposit (Höll and Eichhorn 2000). The deposit consists of a metamorphosed stockwork of deformed quartzscheelite veins, mineralised shear zones with strongly foliated quartz-scheelite ores and disseminated scheelite mineralisation in the host rocks (Raith et al. 2018; Raith and Schmidt 2010). The Upper Magmatic Series is an island (?) arc sequence including various 


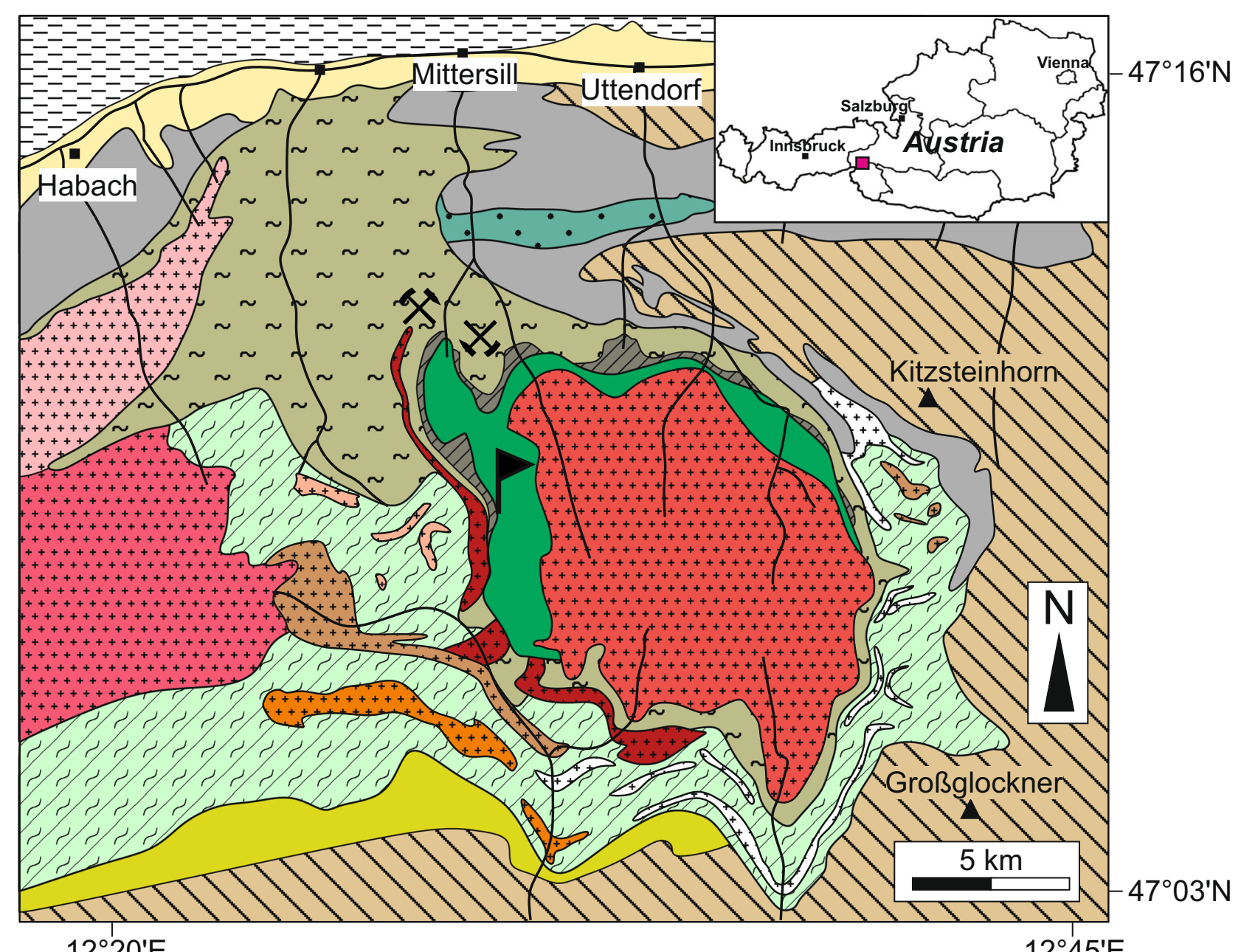

$12^{\circ} 20^{\prime} \mathrm{E}$

$12^{\circ} 45^{\prime} \mathrm{E}$

\section{Pre-Variscan basement}

2/3 Old Gneiss Series (paragneiss, migmatitic gneiss etc.)

$\sim \sim$ Lower Magmatic Series (Metabasite Complex)

. . Zwölferzug (amphibolite, paragneiss etc.)

Basal Amphibolite

\section{Variscan basement}

$\square$ Upper Magmatic Series, Habach Phyllite

\section{(Post-)Variscan granitoids (Zentralgneise)}

\begin{tabular}{|c|c|}
\hline & Felbertauern augengneiss \\
\hline 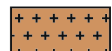 & Hochweißenfeld gneiss \\
\hline $\begin{array}{l}t+++ \\
+++\end{array}$ & Knorrkogel gneiss \\
\hline $\begin{array}{l}+++++ \\
+++++ \\
+++++\end{array}$ & Weißeneck-Dich \\
\hline
\end{tabular}

\section{Zillertal-Venediger gneiss

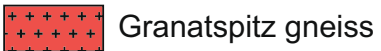 \\ ++++++
+++++ Tux gneiss \\ Undifferentiated granitoids}

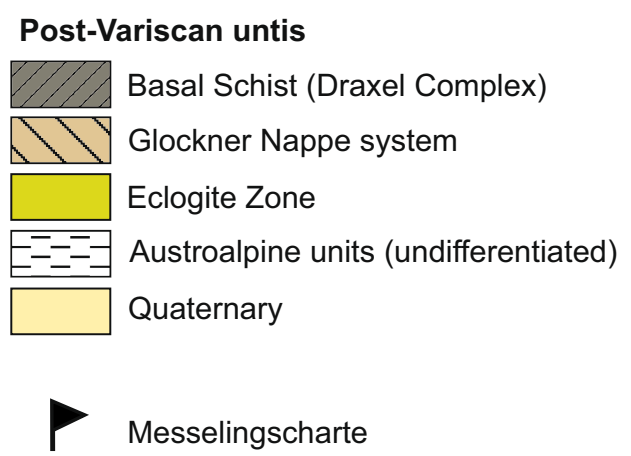

Fig. 1 Simplified geological map of the central Tauern Window showing pre-Variscan and Variscan units and the different types of metagranitoids (Zentralgneise); locations of the Felbertal tungsten deposit (hammer and chisel symbols) and Messelingscharte (flag); modified from Kozlik and Raith (2017) 
metamorphosed basic to acidic calc-alkaline volcanic rocks (Höck 1993) grading into the Habach phyllites. $\mathrm{U}-\mathrm{Pb}$ dating of detrital zircons revealed that it is part of the Variscan basement (Kebede et al. 2005; Pestal et al. 2009).

\section{Analytical methods}

The whole rock major and trace element concentrations were determined for six skarn and 23 host rock (Basal Amphibolite) samples. Between 5 and $10 \mathrm{~kg}$ of rock were crushed in a jaw crusher and a disc mill $(<4 \mathrm{~mm})$ at WBH AG laboratories in Mittersill. Each sample was split using a riffle splitter into representative subsamples $(\sim 300 \mathrm{~g})$. One subsample was milled to a grain size $<63 \mu \mathrm{m}$ using a vibrating cup mill with agate grinding set. The powder was homogenised and $40 \mathrm{~g}$ were taken for chemical analysis.

Whole rock analysis was performed by Bureau Veritas Minerals Laboratories (BVML), Vancouver Office (Canada) (analytical package LF202). The package includes eleven major oxides and Sc determined by solution inductively coupled plasma - atomic emission spectrometry (ICP-AES). Samples were dissolved using lithium borate fusion and dilute acid digestion with hot aqua regia. Additionally, 45 trace elements were analysed by solution inductively coupled plasma - mass spectrometry (ICP-MS). Loss on ignition (LOI) was determined gravimetrically after sintering at $1000{ }^{\circ} \mathrm{C}$. Concentrations of total carbon and sulphur were analysed with a Leco analyser.

$\mathrm{X}$-ray diffraction analysis was performed at the laboratories of WBH AG. A D4 Endeavour Bruker instrument was used equipped with a $\mathrm{Cu}$ cathode and a LynxEye, 1D-detector. The acceleration voltage was $35 \mathrm{kV}$ with a current of $45 \mathrm{~mA}$. The step size was $0.2^{\circ}(2 \mathrm{~s}$ time interval) with 2 Theta measured from 5 to $90^{\circ}$. Quantitative analysis was performed with the Bruker software TOPAS.

$\mathrm{X}$-ray fluorescence (XRF) analysis of W was carried out using a Bruker S4 Pioneer instrument with a Rh cathode at the laboratories of WBH AG. The acceleration voltage was $60 \mathrm{kV}$ with a current of $50 \mathrm{~mA}$. A flow counter was used to resolve the signal. Three different lab-internal calibrations were used to cover the wide ranges of $\mathrm{WO}_{3}$ content: BPRESS $0-0.2 \%$, EPRESS $0.2-3 \%$, PRESS 3-18\%.

Mineral chemical compositions were analysed with the JEOL JXA 8200 superprobe of Universitätszentrum Angewandte Geowissenschaften (UZAG) Steiermark installed at the Chair of Resource Mineralogy, Montanuniversität Leoben, equipped with four wavelengthdispersive spectrometers (WDS). The beam diameter was set in focused mode to a diameter of around $1 \mu \mathrm{m}$. Data were corrected for matrix effects by the ZAF-method. Conditions for scheelite and titanite analyses were $20 \mathrm{kV}$ acceleration voltage and $10 \mathrm{nA}$ beam current; for clinozoisite $15 \mathrm{kV}$ and $10 \mathrm{nA}$ were used. The following standards and lines were used for scheelite: apatite $(\mathrm{Ca} \mathrm{K} \alpha)$, W metal (W L $\alpha$ ), PtSn alloy ( $\operatorname{Sn} \mathrm{L} \alpha$ ), strontianite $(\operatorname{Sr} \mathrm{L} \alpha)$ and Mo metal (Mo $\mathrm{L} \alpha)$; for clinozoisite albite $(\mathrm{Na} \mathrm{K} \alpha$ ), diopside ( $\mathrm{Si} \mathrm{K} \alpha$, $\mathrm{Ca} \mathrm{K} \alpha$ ), rhodonite $(\mathrm{Mn} \mathrm{K} \alpha)$, F-phlogopite (F $\mathrm{K} \alpha, \mathrm{Mg} \mathrm{K} \alpha$ ), magnetite ( $\mathrm{Fe}$ $\mathrm{K} \alpha)$, sanidine $(\mathrm{K} \mathrm{K} \alpha, \mathrm{Al} \mathrm{K} \alpha)$, PtSn alloy $(\mathrm{Sn} \mathrm{L} \alpha)$ and benitoite (Ti K $\alpha$ ); for titanite F-phlogopite (F K $\alpha)$, REE glass $(\mathrm{Al} \mathrm{K} \alpha$ ), rhodonite $(\mathrm{Fe} \mathrm{K} \alpha)$, zircon $(\mathrm{Zr} \mathrm{L} \alpha$, Si K $\alpha$ ), pure $\mathrm{Ta}$ ( Ta $\mathrm{L} \alpha$ ), rutile $(\mathrm{Ti} \mathrm{K} \alpha), \mathrm{Nb}$ metal $(\mathrm{Nb} \mathrm{L} \alpha)$, W metal (W L $\alpha$ ), wollastonite $(\mathrm{Ca} \mathrm{K} \alpha)$ and PtSn alloy $(\mathrm{Sn} \mathrm{L} \alpha)$. Mineral abbreviations are according to Whitney and Evans (2010).

\section{Results}

\section{Scheelite mineralisation}

\section{Scheelite skarn}

Scheelite predominantly occurs in a massive, non-foliated clinozoisite-rich calcic skarn (Fig. 2a, b) and greenish, tightly foliated amphibole schists within amphibolites of the Basal Amphibolite unit. The skarn rocks are hosted in partly strongly foliated amphibolites. They occur as irregular rounded pods/nests up to $2.0 \times 1.5 \mathrm{~m}$ in size. The skarn rock shows a non-oriented grano- to nematoblastic fabric.

The skarn rock is composed of clinozoisite (50\%), quartz (20\%), plagioclase $(15 \%)$, scheelite $(6 \%)$, calcite $(5 \%)$ (modal compositions determined by XRD) with minor to accessory chlorite, titanite, apatite, zircon, pyrite and chalcopyrite. Two types of clinozoisite can be distinguished (Fig. 3a, b). Clinozoisite 1 is coarse-grained forming prismatic to irregular subhedral crystals. The assemblage is stanniferous clinozoisite + scheelite + stanniferous titanite + quartz + plagioclase + calcite. Clinozoisite 2 is finer-grained and occurs in the assemblage clinozoisite + chlorite + quartz \pm calcite; it often forms euhedral crystals inter-grown with quartz showing mosaic texture indicative of metamorphic re-crystallisation (Fig. 3b). Transitions of Clinozoisite 1 to Clinozoisite 2 are also documented. Plagioclase and quartz are fine- to very coarsegrained. Chlorite and calcite fill the interstitial space between clinozoisite. Titanite is fine- to medium-grained forming euhedral (sphenoidal) to anhedral, granular textured grains. Euhedral titanite is very common at the contact of the skarn rock with amphibole schist and is overgrown by Clinozoisite 2.

The scheelite is of variable grain size and shows blue to yellow fluorescence colours in shortwave UV light; about 10 $20 \%$ of the scheelite grains are pale to intense yellow under UV light. Larger scheelite crystals (up to $6.5 \mathrm{~cm}$ ) may show undulose extinction and optical zoning. Normally, the core of 


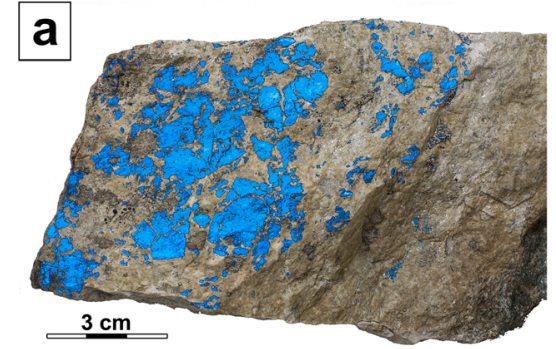

Fig. 2 a Photo of hand specimen of scheelite-rich skarn. Image is combined of two photos (image processing) taken under daylight and shortwave UV light, respectively. Sample 04-22. Scheelite shows blue

larger scheelite crystals is yellow fluorescent surrounded by a blue rim (Fig. 2b).

Amphibole schist forming thin $(\mathrm{cm})$ irregular, discontinuous layers is commonly associated with the skarn, especially at the contact with the host amphibolite. The dark-green amphibole schist is strongly foliated and composed of mediumgrained hornblende (50\%), quartz (30\%) and biotite $(20 \%)$. Accessory minerals are pyrite, apatite, scheelite, chlorite and titanite.

\section{Quartz-scheelite veins}

Scheelite was also found in deformed quartz veins/veinlets and stringers hosted in foliated amphibolite $150-200 \mathrm{~m}$ to the west of Messelingscharte. The deformed thin veins (up to $6 \mathrm{~cm}$, commonly between 2 and $4 \mathrm{~cm}$ ) may show pinchand-swell structures and though they become rotated into the foliation with increasing deformation, they are clearly discordant to the main penetrative foliation (Fig. 4). Scheelite in these veins is up to $8 \mathrm{~mm}$ in size. The fluorescence colour of smaller scheelite crystals is pale blue. Larger scheelite crystals commonly show yellowish cores surrounded by blue rims.

\section{Scheelite in mylonitic quartz-amphibolite layers}

This type of scheelite mineralisation occurs in a topographic depression about $100 \mathrm{~m}$ to the west of Messelingscharte. The $100 \mathrm{~m} \times 50 \mathrm{~m}$ mineralised area terminates sharply to the north

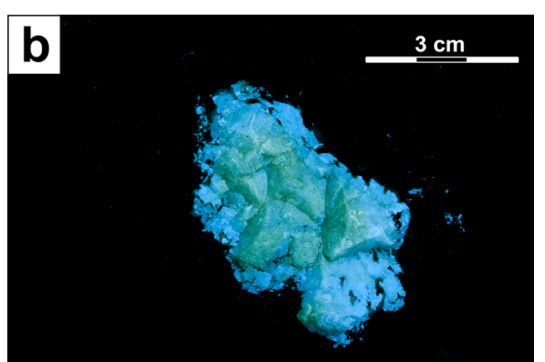

fluorescence. b Photo (short-wave UV light) showing different fluorescence within $\mathrm{cm}$-sized scheelite crystal with a yellowish core and blue rim. Sample 03-18

due to the topography but it could continue to the south underneath Messelingkogel peak. The whole mineralised rock package has a thickness of about 5-10 $\mathrm{m}$. It is characterised by strongly deformed layers of vein quartz that have a thickness of $1-50 \mathrm{~cm}$ and are hosted by fine- to coarse-grained foliated amphibolite with intercalated lenses of hornblende fels. The quartz layers are aligned in the main foliation and show a mylonitic fabric. They likely represent strongly deformed and re-crystallised quartz veins. Disseminated scheelite occurs along the strongly foliated contact between quartz and amphibolite. Only sparse, fine-grained, blue fluorescent scheelite was found.

\section{Whole rock chemistry of skarn rocks}

Results of major and trace element analyses of six skarn samples are listed in Table 1. The main elements are $\mathrm{SiO}_{2}(40.3-$ $55.8 \mathrm{wt} \%), \mathrm{Al}_{2} \mathrm{O}_{3}(17.47-20.9 \mathrm{wt} \%), \mathrm{CaO}(9.06-18.58 \mathrm{wt} \%)$ and $\mathrm{Fe}_{2} \mathrm{O}_{3}$ (4.46-8.56 wt\%). Larger variations are observed for $\mathrm{CaO}, \mathrm{Na}_{2} \mathrm{O}$ and $\mathrm{Fe}_{2} \mathrm{O}_{3}$. The high average $\mathrm{CaO}$ content of $15.3 \mathrm{wt} \%$ mirrors the Ca-rich nature of the skarn. The lower $\mathrm{CaO}$ concentration $(9.06 \mathrm{wt} \%)$ of sample $06-02$ combined with higher $\mathrm{SiO}_{2}$ is explained by the presence of irregular vuggy quartz in this sample. The alkalis show positive correlation with $\mathrm{SiO}_{2}$ whereas $\mathrm{Fe}_{2} \mathrm{O}_{3}, \mathrm{MgO}$ and $\mathrm{CaO}$ tend to decrease with increasing $\mathrm{SiO}_{2}$ contents. Tungsten is present in very high concentrations and is therefore also considered as a major element. The $\mathrm{WO}_{3}$ values range from $0.105-7.74 \mathrm{wt} \%$

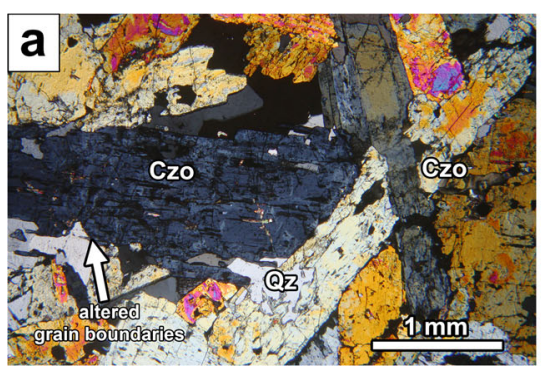

Fig. 3 Photomicrographs of thin sections of scheelite skarn (crossed polariser). a Stanniferous clinozoisite (clinozoisite 1, Czo) associated with quartz. b Clinozoisite $1(\mathrm{Czo})$ with quartz $(\mathrm{Qz})$ and calcite $(\mathrm{Cal})$;

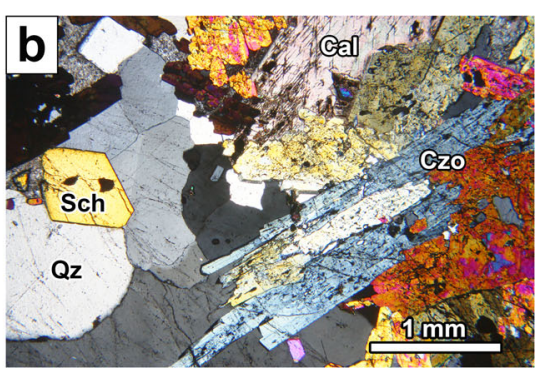

euhedral scheelite (Sch) is inter-grown with re-crystallised quartz; note $\sim 120^{\circ}$ angles between grain boundaries 
Fig. 4 Scheelite-quartz veins (up to $\sim 3 \mathrm{~cm}$ thick) in strongly foliated amphibolite. In UV-light scheelite in the main vein shows a polyphase formation with a yellow fluorescent euhedral core surrounded by a blue rim. Sketch (inset) is redrawn from photograph for clarity

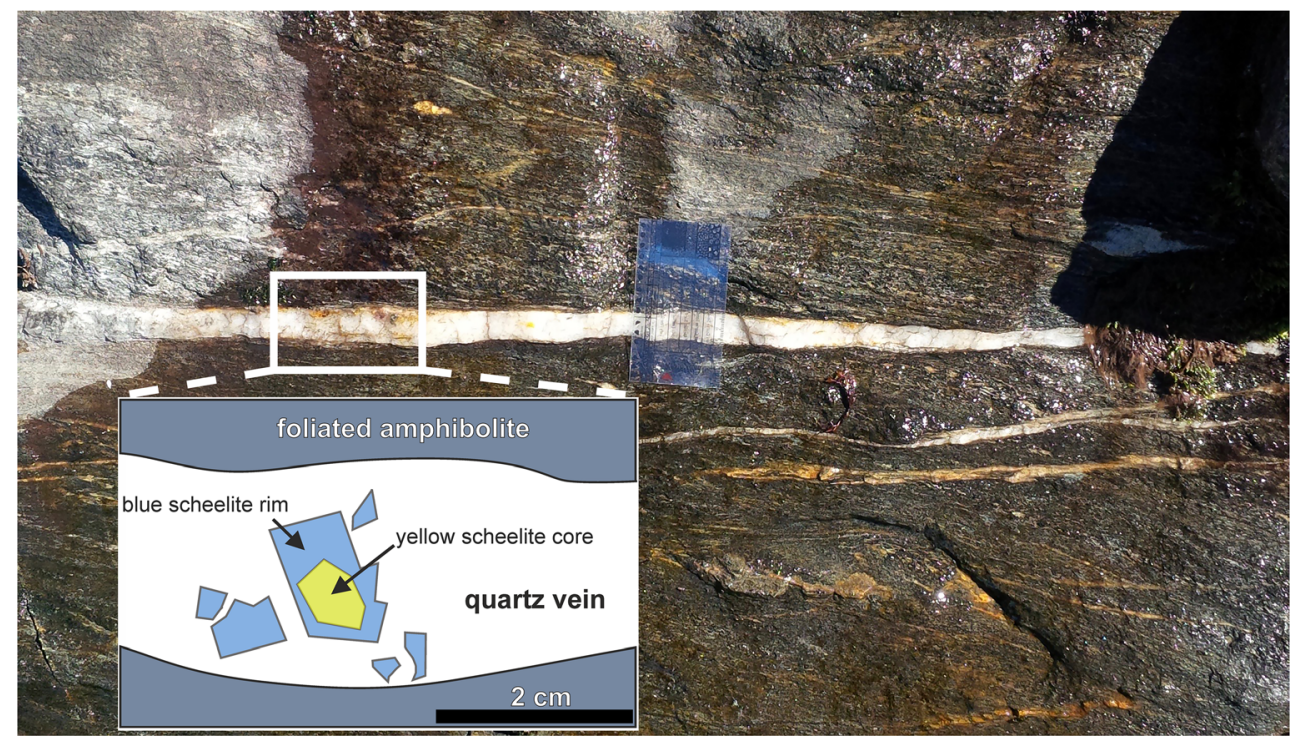

(Table 1). The concentrations of $\mathrm{SiO}_{2}, \mathrm{Al}_{2} \mathrm{O}_{3}$ and $\mathrm{K}_{2} \mathrm{O}$ correlate negatively with $\mathrm{WO}_{3}\left(\mathrm{R}^{2}>0.7\right)$. The $\mathrm{CaO}$ content displays a positive correlation with $\mathrm{W}\left(\mathrm{R}^{2}=0.87\right)$.

As will be outlined below, the skarn formed by interaction of fluids with the metabasite host rocks. Thus, the chemical composition of the calc-silicate rocks was normalised to MORB and is also compared to the host amphibolites of the Basal Amphibolite (Fig. 5a; Table 1). Large ion lithophile elements ( $\mathrm{Cs}, \mathrm{Rb}, \mathrm{Ba}, \mathrm{K}, \mathrm{Sr}$ ), $\mathrm{P}$ and Eu are (strongly) enriched in the calc-silicate rocks compared to MORB whereas the high-field strength (HFS) elements $\mathrm{Ti}, \mathrm{Ta}, \pm \mathrm{Nb}, \mathrm{Hf}, \mathrm{Zr}$ and $\mathrm{Ni}$ are generally depleted. When compared to the host amphibolite the latter elements, however, show strong negative spikes in the spidergram. Thorium values scatter strongly. Other elements like the REE $+\mathrm{Y}$ and $\mathrm{Cr}$ in the skarn show a similar average concentration to MORB but show larger scatter than the amphibolites.

The normalised REE patterns of the skarn rock display a large variation of the REE concentrations ( $\sum$ REE between 41 and 90 ppm) (Fig. 5b). The patterns show low LREE/HREE values $\left((\mathrm{La} / \mathrm{Yb})_{N}=0.2-2.5\right.$; median $\left.=0.8\right)$, decreasing or increasing trend from $\mathrm{La}$ to $\mathrm{Sm}$, strong positive Eu anomalies $\left(\mathrm{Eu} / \mathrm{Eu}^{*}=\mathrm{Eu}_{\mathrm{N}} / \sqrt{ } \mathrm{Sm}_{\mathrm{N}} * \mathrm{Gd}_{\mathrm{N}}=1.7-4.7 ;\right.$ median $\left.=2.0\right)$ and increasing HREE from Gd to Lu. When compared to the amphibolite host rock the strong depletion in LREE, the pronounced positive Eu anomaly and the increase in HREE are obvious (Fig. 5b). The strong positive Eu anomalies and the good correlation of Eu with $\mathrm{Sr}\left(\mathrm{R}^{2}=0.77\right)$ indicate that $\mathrm{Eu}$ is present as a divalent cation.

To assess relative element gains and losses during skarn formation the calc-silicate rocks have also been normalised to the average values of the hosting amphibolite (for complete data set see Ordosch 2017). Some selected elements showing the strongest deviations are illustrated in Fig. 6. For elements with values below the limit of detection in the host amphibolite, the halved detection limit was used for normalisation. In addition to $\mathrm{W}$, which is enriched by a factor of $10^{4}$, $\mathrm{Sn}, \mathrm{Be}, \mathrm{Bi}$ and $\mathrm{U}$ show statistically significant enrichments whereas $\mathrm{Ti}, \mathrm{Zr}$, Hf and $\mathrm{Mg}$ are depleted by a factor 10 (Fig. 6). The average $\mathrm{Zr}$ content in the amphibolite at Messelingscharte is about $\sim 145 \mathrm{ppm}$ whereas the skarn rock contains only about $\sim 24 \mathrm{ppm}$. Hafnium is also depleted although the $\mathrm{Zr} / \mathrm{Hf}$ ratio does not change significantly (amphibolite 40 , skarn $\sim 35$ ). The titanium content in the skarn is also notably lower compared to the host rock (amphibolite $1.41 \mathrm{wt} \% \mathrm{TiO}_{2}$, skarn $0.27 \mathrm{wt} \% \mathrm{TiO}_{2}$ ). Some samples show erratic high concentrations of $\mathrm{Cu}$ and Mo (e.g., 03-17; Table 1). Regarding main components, only Ca shows a slight enrichment; most other main components are slightly depleted (e.g. Fe).

\section{Mineral chemistry}

\section{Scheelite}

In scheelite $\mathrm{Ca}, \mathrm{W}, \mathrm{Mo}, \mathrm{Sr}$ and $\mathrm{Sn}$ were analysed in two skarn samples $\left(03-17^{\prime}, 05-03\right)$ by EMPA. As scheelite is cathodoluminescence (CL) sensitive, CL images were also made (Fig. 7). Molybdenum is the only detectable trace element; it shows a systematic variation (Table 2). Strontium and tin are generally below the detection limit. The major elements $\mathrm{Ca}$ and $\mathrm{W}$ show limited variation; e.g., $\mathrm{CaO}=20.2 \pm$ $0.24 \mathrm{wt} \%$.

Three types of scheelite can be distinguished based on UV fluorescence colour, micro-texture as revealed by CL brightness (EMPA) and $\mathrm{MoO}_{3}$ content (Fig. 7, Table 2). Type 1 scheelite is Mo-bearing with yellow fluorescence colour forming the core of larger scheelite grains. Oscillatory growth 
Table 1 Bulk whole-rock compositions of scheelite-bearing skarn rocks from Messelingscharte by XRF, in weight percent [wt\%] (main oxides) and parts-per million [ppm] (trace elements; $\mathrm{Au}$ in ppb), and the calculated average. Total-C and total-S determined separately by Leco, here reported as oxides. Average composition of the amphibolite host rock (from Ordosch 2017) for comparison. Lower limits of detection given in column LLD; $n d=$ not determined rock type

sample LLD skarn

03-17
04-12
04-17
04

22

host rock*

main rock-forming oxides, in weight percent [wt\%]

$\mathrm{Al}_{2} \mathrm{O}_{3}$

0.01

45.51

51.93

$\mathrm{Fe}_{2} \mathrm{O}_{3}$-total

17.47

19.03

$\mathrm{MgO}$

0.01

8.09

4.79

$\mathrm{CaO}$

0.01

2.65

15.85

0.25

$\mathrm{Na}_{2} \mathrm{O}$

0.01

0.65

$\mathrm{K}_{2} \mathrm{O}$

0.01
0.01

0.18

$\mathrm{TiO}_{2}$

0.01

$$
0.25
$$

0.01

0.12

$\mathrm{MnO}$

0.01

0.15

$\mathrm{Cr}_{2} \mathrm{O}_{3}$

0.002

0.021

$\mathrm{WO}_{3}$

0.0310

7.74

LOI

0.1

$$
2.5
$$

$\mathrm{CO}_{2}$

0.07

0.59

0.05

0.45

sum total

102.22

\subsection{7}

2.1

0.49

0.04

0.75

0.08

0.022

4.82

1.3

$<0.07$

$<0.05$

100.27

40.32

51.68

55.77

18.87

20.3

8.56

2.59

4.46

0.39

18.58

0.34

0.19

0.56

0.29

0.17

0.021

7.16

2.4

0.40

0.57

101.02

13.56

2.88

0.70

0.06

0.52

0.07

0.012

3.35

1.4

$<0.07$

$<0.05$

99.38

\subsection{2}

6.15

1.45

9.06

3.76

1.03

0.33

0.24

0.07

0.012

0.105

2.1

0.22

1.97

trace element contents in $\mathrm{ppm}\left[\mu \mathrm{g} \cdot \mathrm{g}^{-1}\right]$

$\mathrm{Be}$

$\mathrm{Ba}$

Co

$\mathrm{Cs}$

$\mathrm{Ga}$

Hf

$\mathrm{Nb}$

$\mathrm{Rb}$

$\mathrm{Sn}$

$\mathrm{Sr}$

$\mathrm{Sc}$

Ta

Th

U

V

W

$\mathrm{Zr}$

Y

La

$\mathrm{Ce}$

$\operatorname{Pr}$

$\mathrm{Nd}$

$\mathrm{Sm}$

$\mathrm{Eu}$

Gd

$\mathrm{Tb}$

$1 \quad 18$

1

0.2

0.1

0.5

0.1

0.1

0.1

1

0.5

1

0.1

0.2

0.1

8

0.5

0.1

0.1

0.1

0.1

0.02

0.3

0.05

0.02

0.05

0.01

65

20.8

2.7

40.8

1

2.4

7.2

760

786

39

0.1

2.2

2.5

237

nd

29.9

29.4

3.9

8.4

1.19

5.1

1.39

1.01

1.74

0.45

29

297

$$
2.2
$$

2.2

39.1

0.1

1.3

22.8

303

1089

22

$<0.1$

$<0.2$

1.8

131

nd

4.5

48.9

1.7

3.8

0.73

4.7

1.96

4.26

3.86

0.85

$\begin{array}{ll}11 & 40 \\ 81 & 428 \\ 18.1 & 2.8 \\ 5.4 & 3.3\end{array}$

101.59

44.5

1.5

8.4

7.9

640

1049

38

0.4

3.8

2.9

227

nd

58.5

23.1

10.7

23.1

2.93

13.1

2.39

1.32

2.33

0.45

41
475

108.9

4.9

27.2

0.6

3.9

57.2

259

975

1040

22

$<0.1$

0.5

1.9

112

nd

7.3

31.5

1.2 
Table 1 (continued)

\begin{tabular}{|c|c|c|c|c|c|c|c|c|c|}
\hline \multicolumn{2}{|l|}{ rock type } & \multicolumn{7}{|l|}{ skarn } & \multirow{2}{*}{$\begin{array}{l}\text { host rock } * \\
(n=16)\end{array}$} \\
\hline sample & LLD & $03-17$ & 04-12 & $04-17$ & $\begin{array}{l}04- \\
22\end{array}$ & 06-02 & 06-03 & avg. $(n=6)$ & \\
\hline Dy & 0.05 & 3.38 & 5.91 & 2.84 & 3.75 & 1.41 & 1.81 & 3.11 & 4.6 \\
\hline Но & 0.02 & 1.03 & 1.56 & 0.82 & 1.00 & 0.34 & 0.53 & 0.91 & 0.9 \\
\hline Er & 0.03 & 3.23 & 4.82 & 2.89 & 3.49 & 1.19 & 1.86 & 3.06 & 2.6 \\
\hline $\mathrm{Tm}$ & 0.01 & 0.53 & 0.68 & 0.42 & 0.52 & 0.19 & 0.29 & 0.47 & 0.3 \\
\hline $\mathrm{Yb}$ & 0.05 & 4 & 4.55 & 2.9 & 3.61 & 1.04 & 2.14 & 3.26 & 2.3 \\
\hline $\mathrm{Lu}$ & 0.01 & 0.57 & 0.7 & 0.43 & 0.55 & 0.18 & 0.36 & 0.49 & 0.3 \\
\hline Mo & 0.1 & 100 & 10.4 & 35.5 & 13.9 & 4.4 & 9.4 & 12.15 & 0.7 \\
\hline $\mathrm{Cu}$ & 0.1 & 831 & 37.1 & 588 & 96.6 & 2438 & 122 & 355 & 21.3 \\
\hline $\mathrm{Pb}$ & 0.1 & 23.1 & 4 & 8.5 & 5.9 & 19.5 & 4.9 & 7.2 & 1.2 \\
\hline $\mathrm{Zn}$ & 1 & 73 & 8 & 65 & 13 & 94 & 15 & 40 & 22.5 \\
\hline $\mathrm{Ni}$ & 0.1 & 64.3 & 6.7 & 49 & 9.3 & 77.2 & 15.5 & 32.25 & 22.6 \\
\hline As & 0.5 & 1.7 & $<0.5$ & 3.1 & 9.7 & 9.6 & $<0.5$ & 2.4 & 0.4 \\
\hline $\mathrm{Cd}$ & 0.1 & 1.2 & $<0.1$ & 1 & $<0.1$ & 1.3 & 0.1 & 0.55 & $<0.1$ \\
\hline $\mathrm{Bi}$ & 0.1 & 1.5 & 0.3 & 0.5 & 0.4 & 0.6 & 0.5 & 0.5 & $<0.1$ \\
\hline $\mathrm{Ag}$ & 0.1 & 2 & $<0.1$ & 1.5 & 0.3 & 4.4 & 0.2 & 0.9 & $<0.1$ \\
\hline $\mathrm{Au}[\mathrm{ppb}]$ & 0.5 & 3 & $<0.5$ & 2.8 & 5.8 & 5.2 & $<0.5$ & 2.9 & $<0.5$ \\
\hline
\end{tabular}

zoning is typical (Fig. 7). $\mathrm{MoO}_{3}$ contents are up to $1.73 \mathrm{wt} \%$. Blue fluorescent Type 2 scheelite commonly forms overgrowths around older scheelite (Fig. 2b). It contains less Mo (average $\mathrm{MoO}_{3}=0.304 \mathrm{wt} \%$ ) and the $\mathrm{CL}$ images reveal an irregular internal structure. Locally, vague "relict" oscillatory zoning is preserved in Type 2 scheelite (Fig. 7a). It incorporates tiny $(10-100 \mu \mathrm{m})$ inclusions of molybdenite. As there is a compositional gap in $\mathrm{MoO}_{3}$ content at $0.6-0.8 \mathrm{wt} \%$ a threshold value of $0.75 \mathrm{wt} \% \mathrm{MoO}_{3}$ has been used for discrimination between scheelite Types 1 and 2 . Type 3 scheelite is characterised by the lowest Mo contents. The average $\mathrm{MoO}_{3}$ content is $0.06 \mathrm{wt} \%$, but often it is below the detection limit.

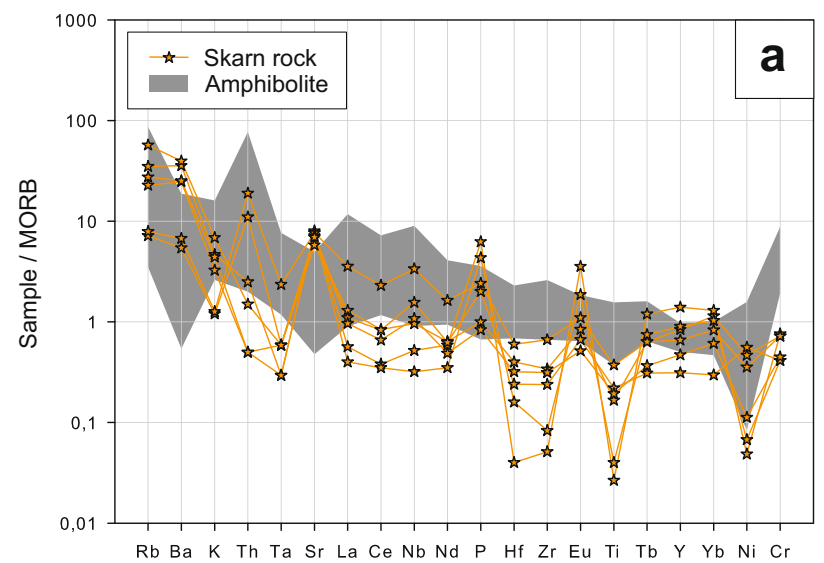

Fig. $5 \mathrm{~W}$-mineralised skarn rocks compared with amphibolite host rocks. a Multi-element spider plots; element concentrations normalised to MORB (values of Pearce et al. 1981 in Bevins et al. 1984). b Chondrite
Type 3 scheelite forms overgrowths on and fills micro-cracks in earlier formed scheelite. No zoning has been observed. Scheelite 3 shows blue fluorescence in UV light.

\section{Clinozoisite}

Clinozoisite was analysed in five skarn samples (03-18, 0412, 05-03, 06-02, 06-03; Table 3). Elements analysed were $\mathrm{Na}, \mathrm{K}, \mathrm{Mg}, \mathrm{Ca}, \mathrm{Mn}, \mathrm{Fe}, \mathrm{Al}, \mathrm{Si}, \mathrm{Ti}, \mathrm{Sn}$ and F. Special consideration was given to $\mathrm{Sn}$ because clinozoisite was identified as the main carrier of this element by qualitative EDS analyses.

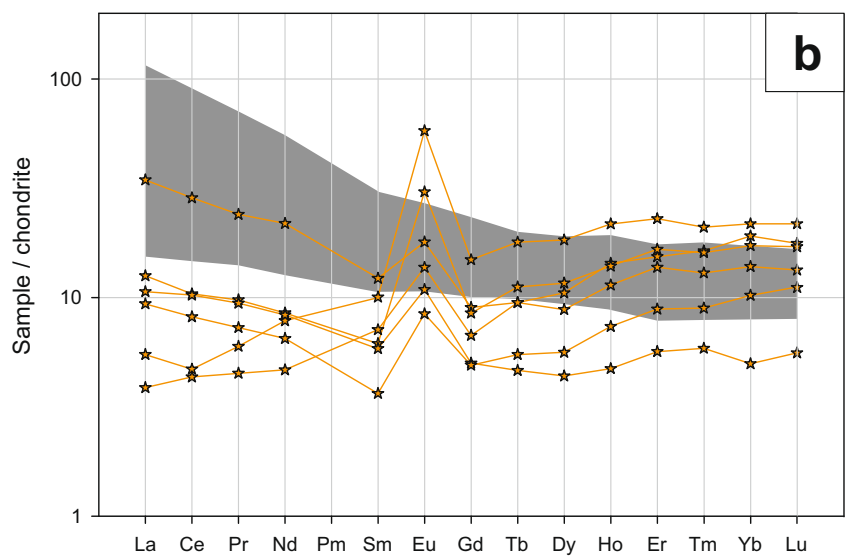

normalised REE patterns; chondrite values from Boynton (1984). In both diagrams, the compositional range of the amphibolite host rock (shaded) is shown for comparison (data from Ordosch 2017) 


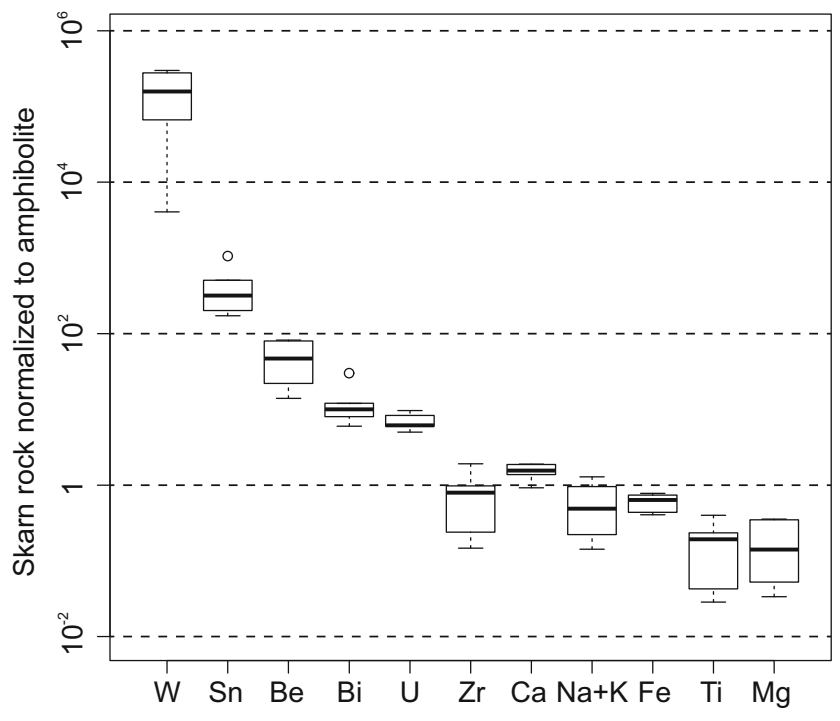

Fig. 6 Boxplots of selected elements showing the strongest enrichment or depletion in the skarn when normalised to the amphibolite host rock. Magnesium and high-field strength HFS elements which are less mobile in hydrothermal fluids like $\mathrm{Ti}$ or $\mathrm{Zr}$ are depleted. Note the strong enrichment of the granitophile elements $\mathrm{W}, \mathrm{Sn}, \mathrm{Be}$

Qualitative scans for REE using wavelength-dispersive spectrometry (WDS) resulted in no detectable REE concentrations.

Clinozoisite is characterised by an average $\mathrm{Al} / \mathrm{Fe}^{3+}$ (apfu) ratio of 4.4 (range: 2.5-9.9) and exceptionally high $\mathrm{Sn}$ contents reaching up to $3.00 \mathrm{wt} \% \mathrm{SnO}_{2}$ (Fig. 8, Table 3). Concentrations of $\mathrm{Na}_{2} \mathrm{O}, \mathrm{K}_{2} \mathrm{O}$ and $\mathrm{MgO}$ are generally very low. The $\mathrm{MnO}$ concentrations can reach up to $0.67 \mathrm{wt} \%(=0.044 \mathrm{apfu} \mathrm{Mn})$ but normally are in the range of $0.1-0.2 \mathrm{wt} \%$. $\mathrm{TiO}_{2}$ is between $0.05-0.1 \mathrm{wt} \%$ but can reach up to $1.60 \mathrm{wt} \%$ (0.09 apfu Ti). Calcium shows minor scatter around 2 apfu with a tendency to be below the ideal content of 2 apfu $\mathrm{Ca}$ in the clinozoisite formula. The reasons

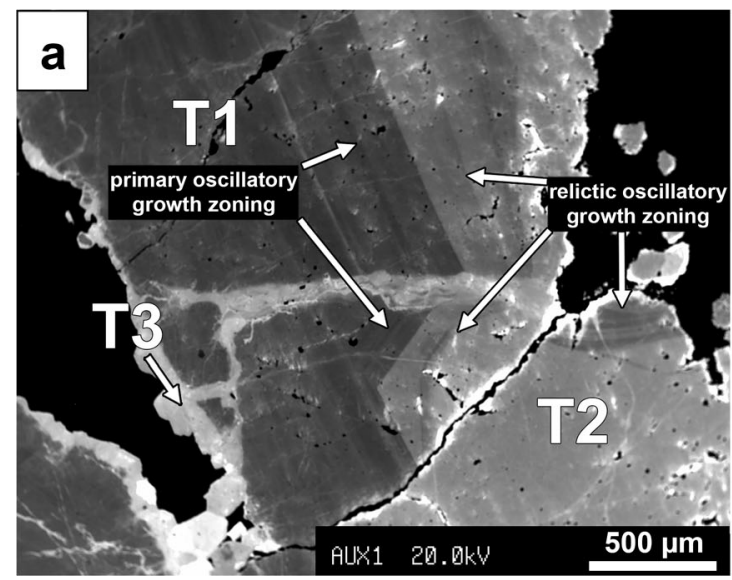

Fig. 7 EMPA Cathodoluminescence (EMPA-CL) images showing the three types of scheelite distinguished at Messelingscharte (sample 03$\left.17^{\prime}\right)$. a Type 1 (T1): dark grey EMPA-CL signal, oscillatory zoning; Type 2 (T2): medium grey EMPA-CL signal, relict oscillatory zoning; for this deficiency are unclear; substitution of $\mathrm{Ba}^{2+}$ or $\mathrm{Sr}^{2+}$ has not been confirmed by EMPA analysis. However, small amounts of $\mathrm{Mn}^{2+}$ substitute for $\mathrm{Ca}$ in the A1-A2 position (e.g. samples $06-03$ an 118 or 06-02 an130 in Table 3; Frei et al. 2004, Armbruster et al. 2006) but an analytical problem for the Ca deficit cannot be excluded.

The petrographic distinction of two types of clinozoisite is confirmed by the mineral chemical data. The first type (Clinozoisite 1) comprising coarsegrained, irregular grains is rich in $\mathrm{Sn}$ and often shows an irregular intra-grain "zoning" based on $\mathrm{Sn} / \mathrm{Ti}$ distribution. High $\mathrm{Sn} / \mathrm{Ti}$ domains normally occur in the relict centre of grains that are incompletely replaced or overgrown by low-Sn clinozoisite (Fig. 8). The vague zoning comprises zones with straight, as well as irregular patchy domain boundaries. Locally, Snpoor clinozoisite (Clinozoisite 2) forms overgrowths/ rims around Clinozoisite 1 or alternates with it, locally with sharp contacts (Fig. 8a, b). Often no welldefined growth zoning is present, likely because of subsequent in-situ replacement or re-crystallisation of Clinozoisite 1 and its transformation into metamorphic Clinozoisite 2. Clinozoisite 2 also forms distinct euhedral, small crystals that clearly represent newly formed metamorphic grains (Fig. 8c). These grains are $\mathrm{Sn}$-poor/free and there is no internal chemical zoning visible.

Clinozoisite also displays two populations with respect to its $\mathrm{Sn}$ concentrations. The low-Sn population is characterised by $\leq 0.3 \mathrm{wt} \% \mathrm{SnO}_{2}(=0.01$ apfu $\mathrm{Sn}$; typical values $0-0.1 \mathrm{wt} \%)$. It incorporates all Clinozoisite 2 grains and several $\mathrm{Sn}$-poor/free measurements of Clinozoisite 1. The high-Sn population reaches values of $3.00 \mathrm{wt} \% \mathrm{SnO}_{2}(=0.094$ apfu;

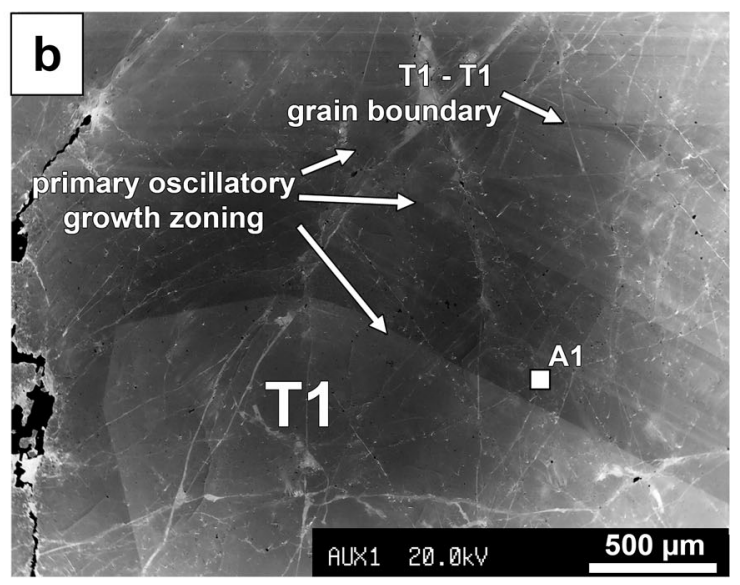

Type 3 (T3): bright (white) EMPA-CL signal; in micro-cracks and thin overgrowths. b Core of Type 1 scheelite with distinct delicate oscillatory growth zoning. The zones showing darker EMPA-CL signal are higher in Mo. Measurements: A1: $1.73 \mathrm{wt} \% \mathrm{WO}_{3}$ 
Table 2 Main element oxide contents of selected scheelite grains, by electron-probe microanalysis (EPMA), in weight percent [wt\%]. Weight percentages of oxides recalculated in atoms per formula unit [apfu] on the basis of four oxygens (4O). The lower part of the table collates cathodoluminescence (EPMA-CL) observations, range of $\mathrm{MoO}_{3}$ contents of scheelite and calculated median value, and calculated scheelite $\left(\mathrm{CaWO}_{4}\right)$ over powellite $\left(\mathrm{CaMoO}_{4}\right)$ ratios in apfu

\begin{tabular}{|c|c|c|c|c|c|c|c|c|c|c|}
\hline \multirow[b]{2}{*}{ species } & \multirow[b]{2}{*}{ LLD } & \multicolumn{9}{|c|}{ scheelite type } \\
\hline & & \multicolumn{3}{|c|}{ 1: crystal core } & \multicolumn{3}{|c|}{ 2: crystal rim } & \multicolumn{3}{|c|}{ 3: perimeter, healed cracks } \\
\hline \multicolumn{11}{|c|}{ main oxide contents, in weight percent [wt\%] } \\
\hline $\mathrm{CaO}$ & 0.0169 & 20.35 & 20.12 & 20.43 & 19.95 & 19.96 & 20.09 & 19.88 & 19.93 & 20.09 \\
\hline $\mathrm{WO}_{3}$ & 0.0722 & 78.30 & 78.77 & 78.29 & 79.84 & 79.62 & 79.27 & 80.10 & 80.25 & 79.95 \\
\hline $\mathrm{MoO}_{3}$ & 0.0180 & 1.27 & 1.08 & 1.39 & 0.17 & 0.36 & 0.61 & 0.07 & 0.04 & 0.03 \\
\hline sum total & - & 99.92 & 99.97 & 100.11 & 99.96 & 100.01 & 99.97 & 100.05 & 100.22 & 100.07 \\
\hline \multicolumn{11}{|c|}{ numbers of cations based on $4 O$, in atoms per formula unit [apfu] } \\
\hline $\mathrm{Ca}$ & - & 1.035 & 1.025 & 1.036 & 1.022 & 1.027 & 1.026 & 1.018 & 1.019 & 1.028 \\
\hline W & - & 0.963 & 0.970 & 0.960 & 0.898 & 0.984 & 0.979 & 0.992 & 0.993 & 0.990 \\
\hline Mo & - & 0.025 & 0.021 & 0.028 & 0.003 & 0.007 & 0.012 & 0.001 & 0.001 & 0.001 \\
\hline sum cations & - & 2.023 & 2.017 & 2.024 & 2.015 & 2.018 & 2.017 & 2.012 & 2.013 & 2.019 \\
\hline \multicolumn{11}{|c|}{ EPMA-CL luminescence observations } \\
\hline \multicolumn{2}{|c|}{ relative brightness } & \multicolumn{3}{|l|}{ dark } & \multicolumn{3}{|c|}{ intermediate } & \multicolumn{3}{|l|}{ bright } \\
\hline \multicolumn{2}{|c|}{ minimum $\mathrm{MoO}_{3}[\mathrm{wt} \%]$} & \multicolumn{3}{|l|}{0.822} & \multicolumn{3}{|c|}{0.100} & \multicolumn{3}{|l|}{ very small } \\
\hline \multicolumn{2}{|c|}{ maximum $\mathrm{MoO}_{3}[\mathrm{wt} \%]$} & \multicolumn{3}{|l|}{1.73} & \multicolumn{3}{|l|}{0.71} & \multicolumn{3}{|l|}{0.10} \\
\hline \multicolumn{2}{|c|}{ median $\mathrm{MoO}_{3}[\mathrm{wt} \%]$} & \multicolumn{3}{|l|}{1.18} & \multicolumn{3}{|l|}{0.30} & \multicolumn{3}{|l|}{0.06} \\
\hline \multicolumn{2}{|c|}{ number of analyses } & \multicolumn{3}{|l|}{104} & \multicolumn{3}{|l|}{65} & \multicolumn{3}{|l|}{16} \\
\hline \multicolumn{2}{|c|}{ scheelite:powellite } & \multicolumn{3}{|l|}{$97.7: 2.3$} & \multicolumn{3}{|c|}{ 99.4: 0.6} & \multicolumn{3}{|l|}{ 99.9: 0.1} \\
\hline
\end{tabular}

typical values $0.5-1 \mathrm{wt} \%$ ). The high-Sn population corresponds to Clinozoisite 1 that has higher Sncontents.

From crystal chemical considerations it is assumed that $\mathrm{Sn}^{4+}$ and $\mathrm{Ti}^{4+}$ are incorporated at the octahedral sites of clinozoisite/epidote where they may substitute for $(\mathrm{A} 1, \mathrm{Fe})^{3+}$ at the M3 site (Frei et al. 2004; Armbruster et al. 2006). For charge balance reasons equivalent amounts to $\mathrm{Sn}^{4+}$ and $\mathrm{Ti}^{4+}$ of divalent cations like $\mathrm{Fe}^{2+}, \mathrm{Mn}^{2+}$ or $\mathrm{Mg}^{2+}$ must be incorporated according to the substitution scheme (1). Excess divalent cations in the M3 position are assigned to the A1 position starting with $\mathrm{Mn}^{2+}$ (Armbruster et al. 2006).

$2(\mathrm{Al}, \mathrm{Fe})^{3+} \Leftrightarrow(\mathrm{Sn}, \mathrm{Ti})^{4+}+(\mathrm{Fe}, \mathrm{Mg}, \mathrm{Mn})^{2+}$

Because the valence of iron cannot be determined with EMPA, $\mathrm{Fe}^{2+}$ was calculated using a modified approach described for clinozosite/epidote in van Marcke de Lummen (1986). A more general approach for silicates and oxides is presented in Droop (1987). It is assumed that there are three $\mathrm{Si}$ atoms per formula unit and the other cations per formula unit sum up to five apfu in the ideal clinozoisite formula $\left(\mathrm{Ca}_{2} \mathrm{Al}_{3}\left(\mathrm{Si}_{2} \mathrm{O}_{7}\right)\left(\mathrm{SiO}_{4}\right) \mathrm{O}(\mathrm{OH})\right)$ (eq. 2).

$a \mathrm{Ca}^{2+}+b \mathrm{Mn}^{2+}+c \mathrm{Mg}^{2+}+d \mathrm{Al}^{3+}+e \mathrm{Fe}^{2+}$

$$
\begin{aligned}
& +f \mathrm{Fe}^{3+}+g \mathrm{Sn}^{4+}+h \mathrm{Ti}^{4+} \\
& =5
\end{aligned}
$$

Moreover, charge balance has to be maintained (eq. 3). The coefficients represent the assumed charge for the cation.

$$
\begin{aligned}
& 2 a \mathrm{Ca}^{2+}+2 b \mathrm{Mn}^{2+}+2 c \mathrm{Mg}^{2+}+3 d \mathrm{Al}^{3+}+2 e \mathrm{Fe}^{2+} \\
& \quad+3 f \mathrm{Fe}^{3+}+4 g \mathrm{Sn}^{4+}+4 h \mathrm{Ti}^{4+} \\
& \quad=13
\end{aligned}
$$

Subtraction of (eq. 1) from (eq. 2) results in (eq. 4).

$$
f \mathrm{Fe}^{3+}=3-d A l^{3+}-2 g \mathrm{Sn}^{4+}-2 h \mathrm{Ti}^{4+}
$$

Equation 4 allows the calculation of the proportion of $\mathrm{Fe}^{3+}$ (in apfu) from measured $\mathrm{FeO}_{\text {tot }}$ as $\mathrm{FeO}_{\text {calc }}=\mathrm{Fe}^{2+} /$ $\left(\mathrm{Fe}^{2+}+\mathrm{Fe}^{3+}\right) * \mathrm{FeO}_{\text {tot }}\left(\mathrm{Fe}^{2+}, \mathrm{Fe}^{3+}\right.$ in apfu, $\mathrm{FeO}_{\text {calc }}$ and $\mathrm{FeO}_{\text {tot }}$ in $\mathrm{wt} \%$ ). The $\mathrm{Fe}_{2} \mathrm{O}_{3}$ calc value is calculated using the residual $\mathrm{FeO}\left(\mathrm{FeO}_{\text {remain }}=\mathrm{FeO}_{\text {tot }}-\mathrm{FeO}_{\text {calc }}\right)$. The recalculated $\mathrm{FeO}$ content reaches up to $2.82 \mathrm{wt} \%$ (median $0.38 \mathrm{wt} \%$ ). In the investigated clinozoisites, only $\mathrm{Fe}^{2+}$ 


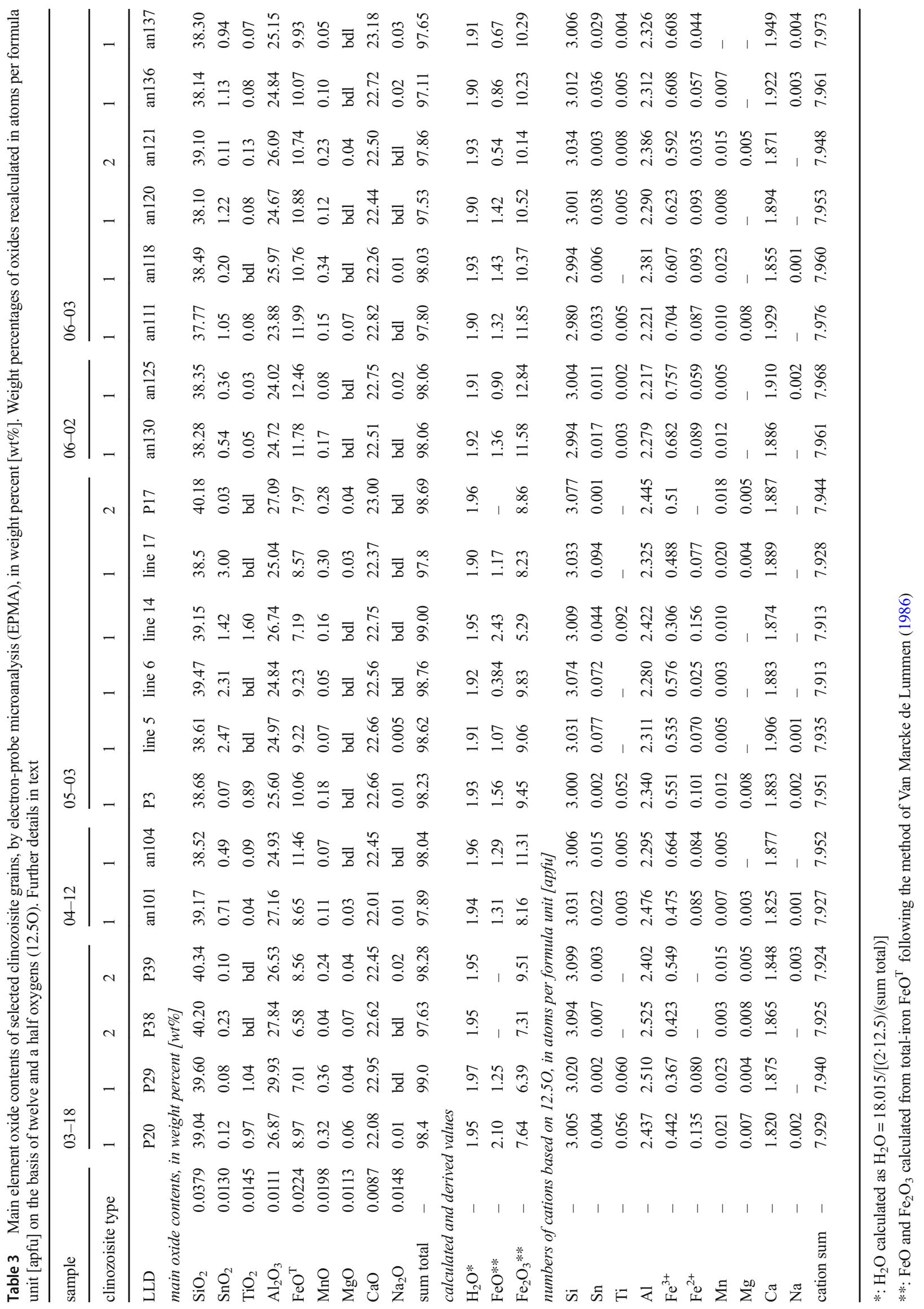



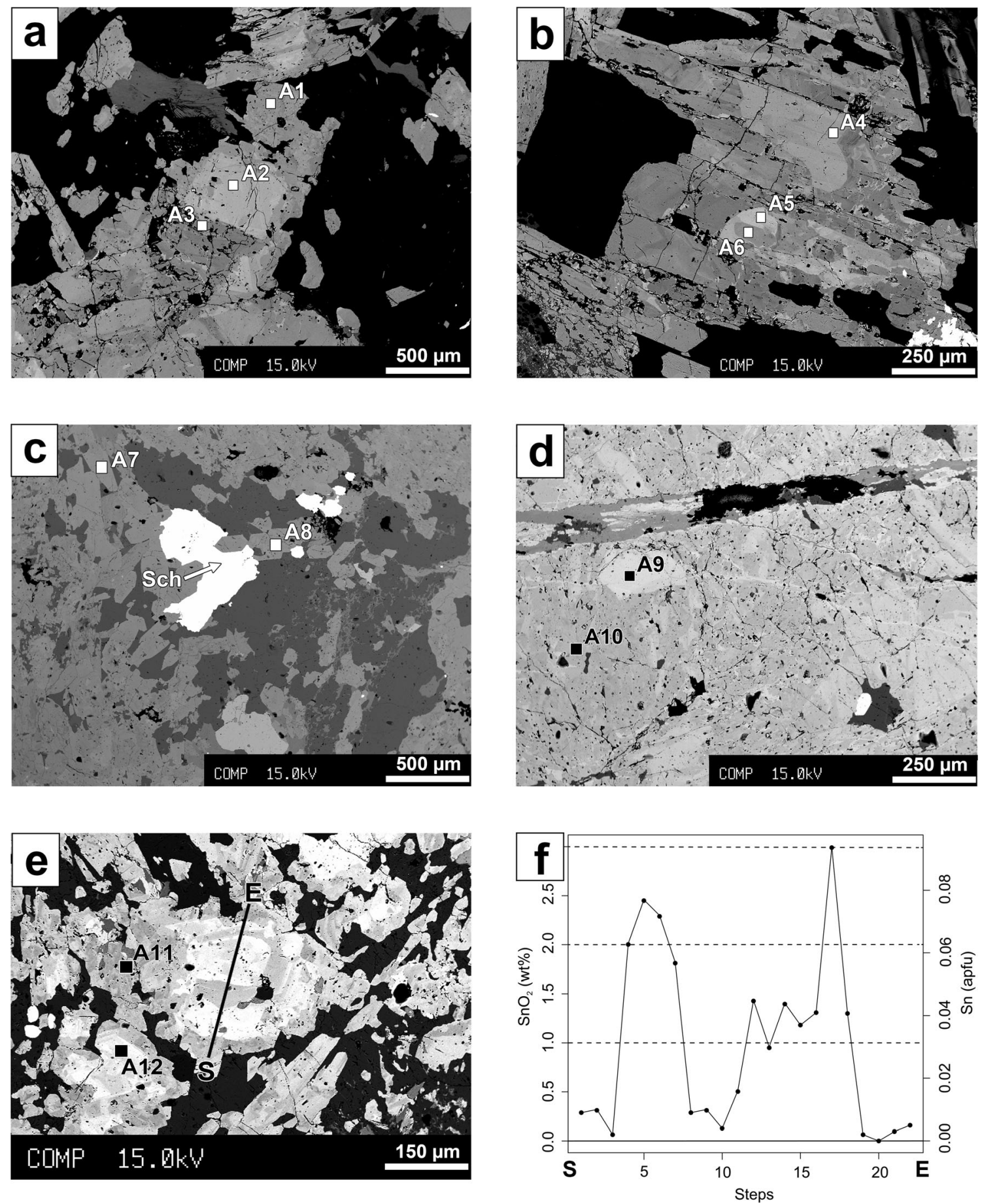

Fig. 8 a-d Back-scattered electron (BSE) images showing micro-textural relationships of the two clinozoisite types. Brighter Sn-rich clinozoisite shows linear to irregular patchy zoning and is intergrown with Sn-poor/ free medium-grey domains. Black area in a is quartz; micro-crack in $\mathbf{d}$ is filled with quartz, carbonate and chlorite. a,b sample 06-03; c,d sample 03-18; e sample 05-03. Measurements (for named measurement points see Table 3): A1: 920 ppm $\mathrm{SnO}_{2}$; A2: $0.70 \mathrm{wt} \% \mathrm{SnO}_{2}$; $\mathrm{A} 3:<130 \mathrm{ppm}$ $\mathrm{SnO}_{2}$; A4: 06-03 an118, 0.20 wt $\% \mathrm{SnO}_{2}$; A5: 06-03 an120, $1.22 \mathrm{wt} \%$

significantly contributes to the charge balance because the $\mathrm{Mn}$ and $\mathrm{Mg}$ concentrations are mostly negligible. The recalculated clinozoisite analyses show a striking

$\mathrm{SnO}_{2}$; A6: 06-03 an121, 0.11 wt $\% \mathrm{SnO}_{2} ; \mathrm{A} 7: 03-18 \mathrm{P} 39,0.10 \mathrm{wt} \%$ $\mathrm{SnO}_{2}$; A8: 03-18 P38, 0.23 wt $\% \mathrm{SnO}_{2}$; A9: 0.49 wt\% $\mathrm{SnO}_{2}$; A10: $<130 \mathrm{ppm}$ wt $\% \mathrm{SnO}_{2}$. e BSE image of clinozoisite displaying complex intergrowths and zoning. The brightest domains/zones are highest in $\mathrm{SnO}_{2}$. Measurements: A11: 05-03 P17, 0.03 wt $\% \mathrm{SnO}_{2}$; A12: $1.13 \mathrm{wt} \% \mathrm{SnO}_{2}$. f Line scan along profile S-E shown in e. Step size is about $15 \mu \mathrm{m}$. The $\mathrm{SnO}_{2}$ content correlates with the brightness in the BSE image

fit to the ideal substitution (1) (Fig. 9). The calculated regression line has a slope of -0.51 (ideally -0.50 ) and the fit of the data is 0.94 . Therefore, it is obvious that 
Fig. 9 Plot $\Sigma \mathrm{Sn}+\mathrm{Ti}$ vs. $\Sigma \mathrm{Al}+$ $\mathrm{Fe}^{3+}$ (in atoms per formula unit, apfu) illustrating substitution (1) in clinozoisite; see text. Dashed line represents the ideal substitution line. The calculated regression line is identical with the ideal substitution line for $95 \%$ confidence

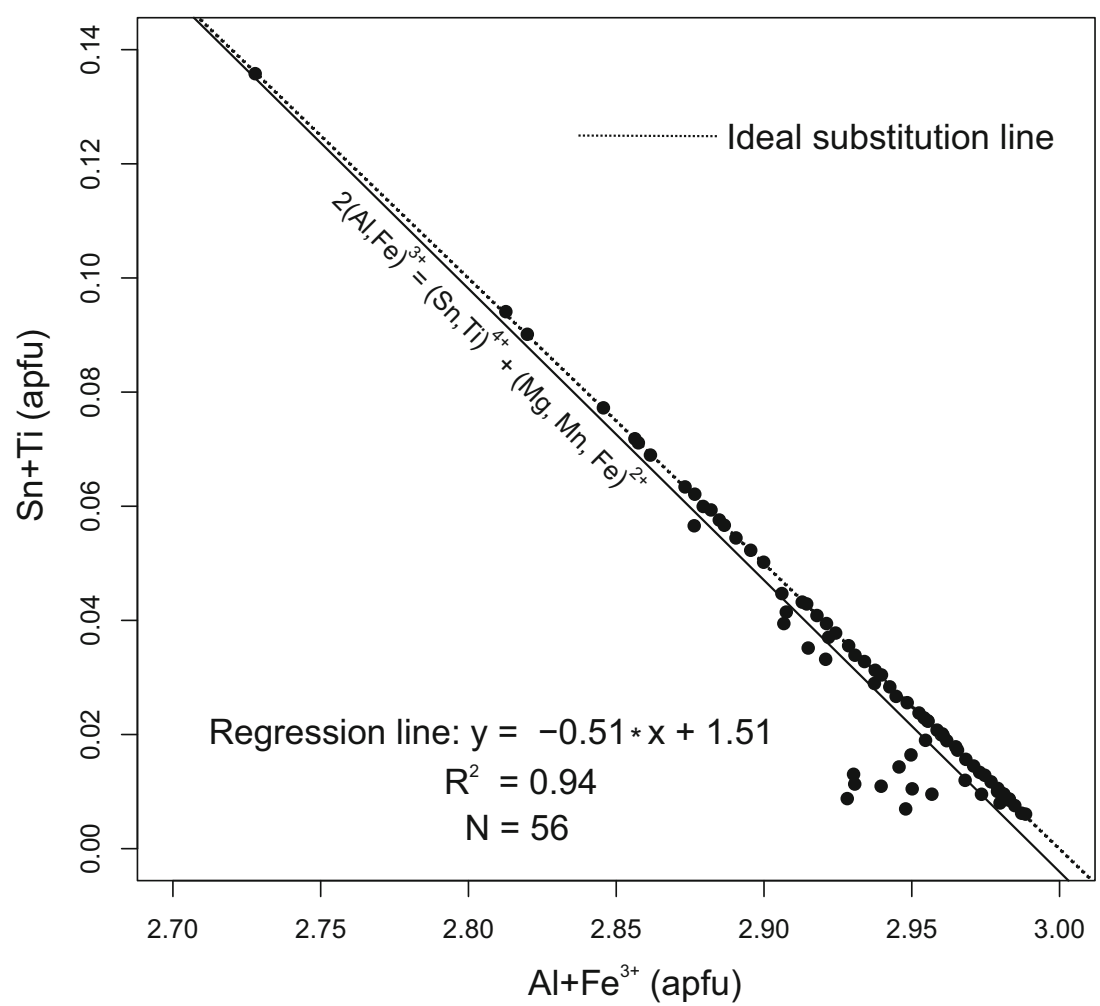

divalent cations are not substituting significantly for $\mathrm{Ca}$ on the A1-A2 site in clinozoisite.

\section{Titanite}

Titanite was analysed in two samples (03-18, 05-03). The measured elements were $\mathrm{Ca}, \mathrm{Ti}, \mathrm{Si}, \mathrm{Al}, \mathrm{Fe}, \mathrm{F}, \mathrm{Sn}, \mathrm{Zr}, \mathrm{Nb}, \mathrm{Ta}$ and W. Mineral formulae were calculated on the basis of $1 \mathrm{Si}$ atom and $\mathrm{OH}$ using the computer program of Ulmer (1993) (Table 4).

In backscatter electron images titanite shows patchy irregular internal zoning (Fig. 11a, c, d). Occasionally, 1-3 $\mu \mathrm{m}$ roundish micro-inclusions of cassiterite and zircon are observed (Fig. 11a). Accumulations of euhedral titanite grains typically occur at the contact between the amphibolite schist and the skarn. In a few titanite aggregates inclusions of rutile and ilmenite are preserved (Fig. 11b). The patchy zoning is defined by element variations between relatively $\mathrm{Sn}-\mathrm{Al}$-richer and $\mathrm{Ti}-\mathrm{Fe}-$ richer intra-grain domains (Fig. 11c, d). Comparable irregular patchy zoning has been reported from zircons from high-grade metamorphic rocks (Corfu et al. 2003). Formation of this type of zoning in zircon has been explained by metasomatic processes and fluid interaction during metamorphism or hydrothermal overprint of older zircon material; it is interpreted as a disequilibrium texture. A similar intra-grain process is envisaged for titanite at Messelingscharte. Older Snrich titanite transforms to Sn-poor titanite in the presence of a metamorphic fluid.

Titanite has a very variable content of $\mathrm{SnO}_{2}$ ranging from 0.07 to $6.48 \mathrm{wt} \%$ (median $2.29 \mathrm{wt} \%$; Table 4). This corresponds to 0.01-0.09 apfu Sn (median 0.03 apfu). Statistically only one population of titanite can be identified in the data set. Titanite shows a complete solid solution with malayaite $\left[\mathrm{CaSnSiO}_{4}(\mathrm{O}, \mathrm{OH}, \mathrm{F})\right]$ above $600{ }^{\circ} \mathrm{C}$ according to the following substitution mechanism (Takenouchi 1971):

$\mathrm{Sn}^{4+} \Leftrightarrow \mathrm{Ti}^{4+}$

The $\mathrm{F}$ concentrations of titanite range between $0.5-$ $1.6 \mathrm{wt} \%$ (median $=1.1 \mathrm{wt} \% ; 0.12 \mathrm{apfu}$ ). The $\mathrm{CaO}$ values vary only slightly with an average of $26.54 \mathrm{wt} \%$ (=0.97 apfu). Ca has to be $1 \mathrm{apfu}$ in the ideal formula of titanite. Our results are $<1$ apfu Ca falling short by $\sim 0.03$ apfu. One possibility for the deficiency in $\mathrm{Ca}$ could be incorporation of REE in the $\mathrm{Ca}$ position. However, qualitative WDS analysis of Sn-poor and Sn-rich portions of titanite resulted in no detectable REE. An alternative explanation for $\mathrm{Ca}$ deficiency could be the substitution $\mathrm{Ca}^{2+} \Leftrightarrow 2 \mathrm{H}^{+}$(Hollabaugh and Rosenberg 1983).

Substitution of $\mathrm{F}$ in titanite has been proposed according to the following substitution (Ribbe 1982; Sahama 1946):

$$
(\mathrm{Al}, \mathrm{Fe})^{3+}+(\mathrm{OH}, \mathrm{F}) \Leftrightarrow \mathrm{Ti}^{4+}+\mathrm{O}^{2-}
$$


Table 4 Main element oxide contents of selected titanite grains, by electron-probe microanalysis (EPMA), in weight percent [wt\%]. Weight percentages of oxides are recalculated in atoms per formula unit [apfu] on the basis of one silicon (1Si)

\begin{tabular}{|c|c|c|c|c|c|c|c|c|c|}
\hline \multicolumn{2}{|l|}{ sample } & \multicolumn{2}{|l|}{ 03-18 } & \multicolumn{6}{|l|}{ 05-03 } \\
\hline & LLD & $\mathrm{P} 40$ & $\mathrm{P} 43$ & P5 & P8 & $\mathrm{P} 15$ & P16 & P26 & P34 \\
\hline $\mathrm{SiO}_{2}$ & 0.0123 & 29.89 & 29.71 & 28.99 & 30.02 & 29.80 & 28.91 & 29.88 & 30.31 \\
\hline $\mathrm{SnO}_{2}$ & 0.0134 & 0.32 & 4.84 & 5.51 & 3.03 & 1.18 & 6.48 & 3.76 & 3.02 \\
\hline $\mathrm{TiO}_{2}$ & 0.3215 & 38.30 & 32.11 & 33.85 & 31.02 & 39.00 & 31.57 & 36.10 & 35.72 \\
\hline $\mathrm{Al}_{2} \mathrm{O}_{3}$ & 0.0125 & 2.43 & 4.83 & 2.58 & 6.77 & 2.09 & 3.39 & 3.10 & 3.13 \\
\hline $\mathrm{FeO}^{\mathrm{T}}$ & 0.0134 & 0.39 & 0.85 & 1.65 & 1.39 & 0.50 & 1.26 & 0.57 & 0.84 \\
\hline $\mathrm{CaO}$ & 0.0065 & 27.16 & 26.80 & 26.20 & 26.37 & 26.94 & 26.19 & 26.89 & 27.02 \\
\hline $\mathrm{F}$ & 0.0396 & 0.65 & 1.39 & 0.83 & 1.35 & 0.67 & 1.20 & 1.00 & 1.06 \\
\hline sum total & - & 98.86 & 99.93 & 99.25 & 99.56 & 99.89 & 98.51 & 100.88 & 99.66 \\
\hline \multicolumn{10}{|c|}{ calculated and derived values } \\
\hline $\mathrm{H}_{2} \mathrm{O}^{*}$ & - & 0.17 & 0.30 & 0.27 & 0.73 & 0.11 & 0.19 & 0.15 & 0.16 \\
\hline$-\mathrm{O}=\mathrm{F}^{* *}$ & - & 0.27 & 0.58 & 0.35 & 0.57 & 0.28 & 0.50 & 0.42 & 0.45 \\
\hline \multicolumn{10}{|c|}{ numbers of ions based on 1Si, in atoms per formula unit [apfu] } \\
\hline $\mathrm{Si}$ & - & 1.000 & 1.000 & 1.000 & 1.000 & 1.000 & 1.000 & 1.000 & 1.000 \\
\hline $\mathrm{Sn}$ & - & 0.004 & 0.065 & 0.073 & 0.040 & 0.016 & 0.089 & 0.050 & 0.027 \\
\hline $\mathrm{Ti}$ & - & 0.964 & 0.813 & 0.849 & 0.777 & 0.984 & 0.821 & 0.909 & 0.886 \\
\hline $\mathrm{Al}$ & - & 0.096 & 0.191 & 0.101 & 0.264 & 0.082 & 0.138 & 0.122 & 0.122 \\
\hline $\mathrm{Fe}^{3+}$ & - & 0.011 & 0.024 & 0.046 & 0.038 & 0.014 & 0.037 & 0.016 & 0.023 \\
\hline $\mathrm{Ca}$ & - & 0.974 & 0.966 & 0.936 & 0.935 & 0.969 & 0.971 & 0.964 & 0.955 \\
\hline $\mathrm{F}$ & - & 0.069 & 0.148 & 0.087 & 0.142 & 0.071 & 0.131 & 0.106 & 0.110 \\
\hline $\mathrm{O}^{\dagger}$ & - & 0.893 & 0.784 & 0.853 & 0.698 & 0.904 & 0.825 & 0.862 & 0.856 \\
\hline $\mathrm{OH}+$ & - & 0.038 & 0.068 & 0.060 & 0.160 & 0.025 & 0.044 & 0.032 & 0.034 \\
\hline sum & - & 4.049 & 4.059 & 4.005 & 4.054 & 4.065 & 4.056 & 4.061 & 4.013 \\
\hline
\end{tabular}

*: $\mathrm{H}_{2} \mathrm{O}$ calculated as $\mathrm{H}_{2} \mathrm{O}=$ normalised $\mathrm{H}_{2} \mathrm{O} * 18.0153 / 2$

**: excess $\mathrm{F}=\mathrm{O}(\mathrm{wt} \%)$ calculated using molar weights as: $\mathrm{wt} \% \mathrm{~F}_{*} \mathrm{M}_{\mathrm{O}} /\left(2 * \mathrm{M}_{\mathrm{F}}\right)$

$\dagger$ : excess $\mathrm{O}$ (apfu) was calculated $\mathrm{O}=1-\mathrm{OH}-\mathrm{F}$

†: $\mathrm{OH}$ was calculated cf. Ulmer $(1993)$ as $\mathrm{OH}=\left[\mathrm{Al}+\mathrm{Fe}^{3+}\right]-\mathrm{F}$, assuming all $\mathrm{Fe}$ as trivalent

The titanites analysed show a good negative correlation of $\mathrm{F}$ with $\mathrm{Ti}$ (Fig. 10a). Aluminium and iron are the main substituents for $\mathrm{Ti}(+\mathrm{Sn})$ (Fig. 10b) confirming substitution (6). The slope of the calculated regression line is -0.99 (ideally -1.00 ) which indicates that titanium and all the other substituting cations ( $\mathrm{Fe}, \mathrm{Al}, \mathrm{Sn})$ follow a 1:1 trend as postulated by substitution (6).

Oberti et al. (1991) classified titanite into high-aluminous $\mathrm{x}_{\mathrm{Al}}>0.25$ and low-aluminous $\mathrm{x}_{\mathrm{Al}}<0.25$ ones $\left(\mathrm{x}_{\mathrm{Al}}=\mathrm{Al} /\right.$ $(\mathrm{Al}+\mathrm{Fe}+\mathrm{Ti})$. Here, a modified calculation of $\mathrm{x}_{\mathrm{Al}}=\mathrm{Al} /$ $(\mathrm{Al}+\mathrm{Fe}+\mathrm{Sn}+\mathrm{Ti})$ is used to include $\mathrm{Sn}$. Values of $\mathrm{x}_{\mathrm{Al}}$ for Messelingscharte titanites range from $0.075-0.236$ with a median of 0.125 ; i.e. all titanites are classified as low-Al titanites.

The substitution of $\mathrm{Ti}$ by $\mathrm{Sn}$ (substitution (5)) is coupled with preferred incorporation of $\mathrm{Fe}^{3+}$ over $\mathrm{Al}^{3+}$ as can be seen from wavelength-dispersive (WDS) element mappings (Fig. $11 \mathrm{c}$, d). Incorporation of $\mathrm{Sn}^{4+}$ limits incorporation of $\mathrm{Al}^{3+}+(\mathrm{F}, \mathrm{OH})^{-}$(Groat et al.
1985; Higgins and Ribbe 1976; Kunz et al. 1997; Oberti et al. 1991).

\section{Discussion}

\section{Polyphase formation of scheelite and clinozoisite}

One key question is the genetic relationship of the $\mathrm{W}-(\mathrm{Sn})$ mineralisation at Messelingscharte to the nearby Felbertal tungsten deposit, which is a major global tungsten mine outside China (Raith et al. 2018). Here we discuss how the scheelite types from Messelingscharte are comparable to the scheelite "stages" reported from the Felbertal deposit (Table 5, Höll and Eichhorn 2000).

The three scheelite types at Messelingscharte are interpreted to have formed during different geological events. The Mo-bearing Type 1 (scheelite: powellite 97.7: 2.3) is 

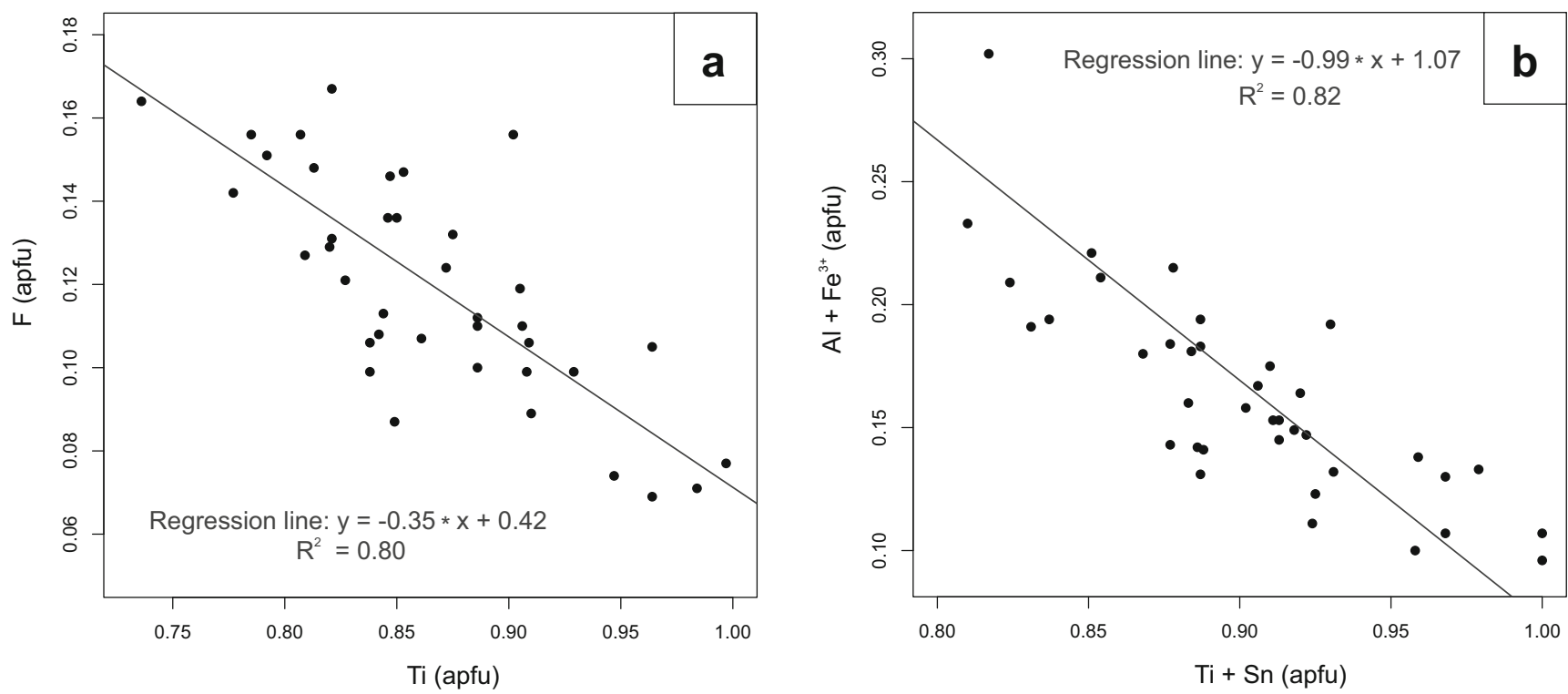

Fig. 10 Binary plots (values in apfu) of chemical composition of titanite. a $\mathrm{Ti}$ vs. $\mathrm{F}$; b $\mathrm{Ti}+\mathrm{Sn}$ vs. $\mathrm{Al}+\mathrm{Fe}^{3+}$

believed to have formed by magmatic hydrothermal processes (see below). It is best correlated with the coarse-grained Mobearing Stage 2 scheelite at the Felbertal deposit.

Type 2 scheelite at Messelingscharte containing less Mo (scheelite: powellite 99.4: 0.6) formed by incomplete metamorphic replacement and re-crystallisation of Type 1 scheelite. It caused partial obliteration of the oscillatory zoning inherited from Type 1 scheelite (Fig. 12) and the formation of tiny molybdenite inclusions due to breakdown of Mobearing Type 1 scheelite. Moreover, undulose extinction of larger scheelite grains/aggregates records deformation and incomplete re-crystallisation of scheelite. Hence, we interpret Type 2 scheelite as a first stage of metamorphic overprint of unclear age although Mo-poor scheelite is also common in oxidised skarns (Meinert et al. 2005) and is commonly formed during the late skarn stage (e.g., King Island, Kwak and Tan
Fig. 11 a, b BSE pictures of titanite. a Typical euhedral, twinned, patchy-zoned titanite within quartz (black); a micrometer size inclusion of cassiterite is outlined (sample 06-03). b Titanite with inclusions of rutile and ilmenite (sample 06-02). c, d Wave-length dispersive (WDS) element mappings of a titanite grain showing distinct internal heterogeneity for $\mathrm{Sn}(\mathbf{c})$ and $\mathrm{Fe}$ (d). Sn-rich intra-grain domains are always higher in $\mathrm{Fe}$ and lower in Al. There is a miniscule cassiterite inclusion (arrow) visible in the Sn map. Nearby clinozoisite (white circle) also contains detectable Sn. Grain boundaries are outlined for clarity
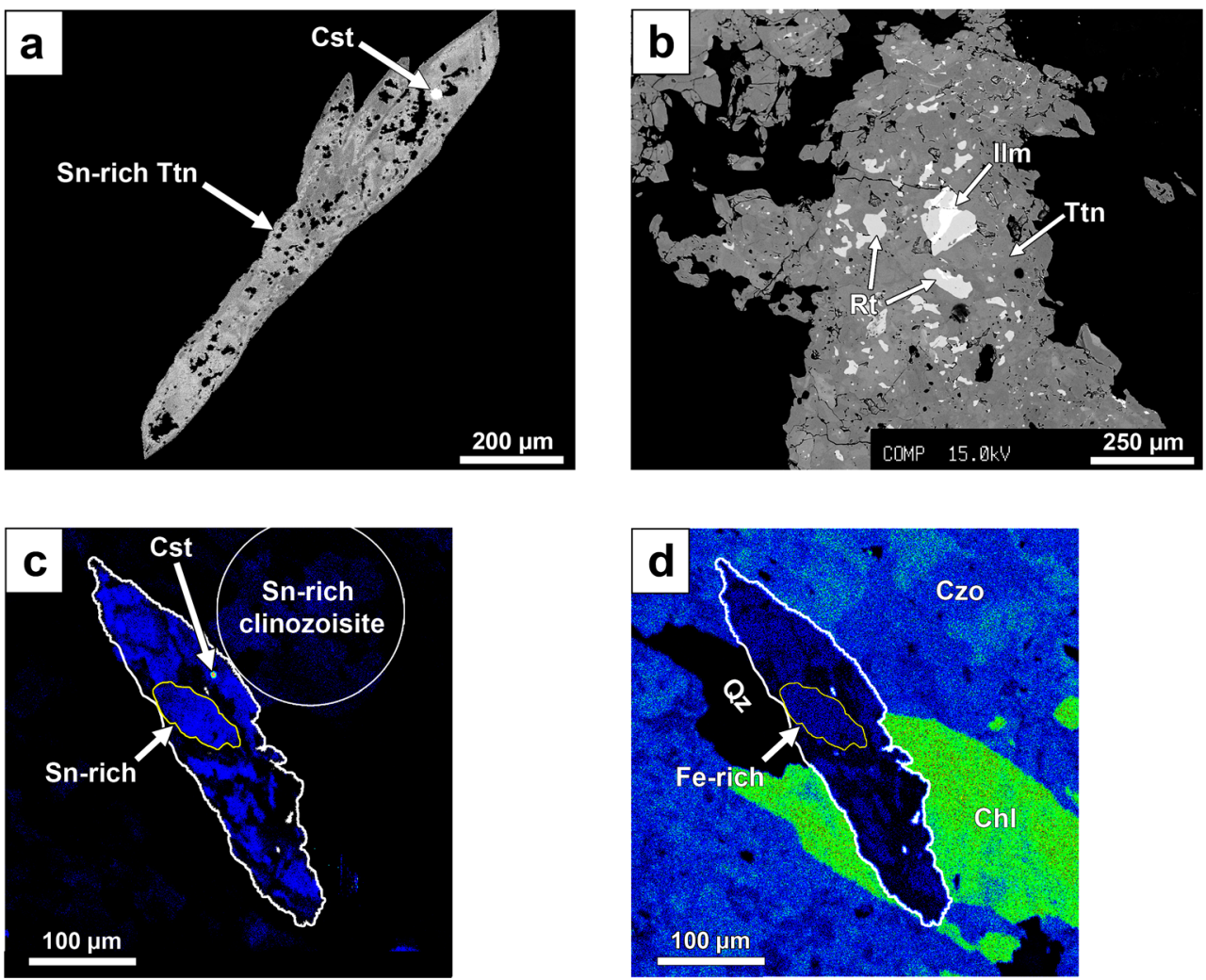
1981). Tentatively Type 2 could be correlated with metamorphic Stage 3 scheelite at Felbertal that formed during breakdown of older Mo-richer scheelite stages (Raith and Stein 2006).

Type 3 scheelite (scheelite: powellite 99.9: 0.1) at Messelingscharte is also the product of metamorphic re-crystallisation and in situ replacement of older Mobearing by Mo-poor scheelite. It is best compared with metamorphic Stage 3 scheelite from Felbertal, which has been interpreted as metamorphic scheelite of Variscan age (Eichhorn et al. 1997; Raith and Stein 2006). Considering the geological context, the dominant metamorphic overprint at Messelingscharte is, however, thought to be Alpine; hence, regarding its age Type 3 scheelite from Messelingscharte would be comparable with Stage 4 at Felbertal. This apparent discrepancy can be resolved if we consider that the grade of Alpine regional metamorphism is increasing towards south from greenschist facies at Felbertal to amphibolite facies conditions at Messelingscharte (Hoernes and Friedrichsen 1974); at Felbertal the maximum metamorphic grade was reached during the Variscan orogeny.
Petrographic observations as well as mineral chemical data indicate that, similar to scheelite, clinozoisite records a polyphase formation. Stanniferous Clinozoisite 1 is considered to belong to the primary hydrothermal mineral assemblage together with Type 1 scheelite and stanniferous titanite. As discussed below the high contents of $\mathrm{Sn}$ and $\mathrm{Ti}$ exclude its metamorphic formation. Clinozoisite 2 is the product of partly incomplete metamorphic replacement and re-crystallisation of Clinozoisite 1 . It is noteworthy that metamorphism dispersed Sn resulting in lower Sn content of Clinozoisite 2. Because the latter occurs in mutual grain contact (i.e., equilibrium) with re-crystallised quartz and Type 3 scheelite we think it formed during Alpine (c. $30 \mathrm{Ma}$ ) Barrovian type regional metamorphism in the Tauern Window (Frank et al. 1987).

\section{Comparison with other occurrences}

\section{Stanniferous clinozoisite}

As documented in this study, clinozoisite from Messelingscharte incorporates higher quantities of $\mathrm{Sn}^{4+}$

Table 5 Comparison and tentative correlation of scheelite at Messelingscharte (this study) with scheelite stages at Felbertal tungsten deposit. Data for scheelite from Felbertal compiled from Höll and Eichhorn (2000) and other sources

\section{MESSELINGSCHARTE}

\begin{tabular}{|c|c|c|c|c|}
\hline & \multicolumn{2}{|l|}{ Type 1} & Type 2 & Type 3 \\
\hline $\begin{array}{l}\text { fluorescence } \\
\text { colour }\end{array}$ & \multicolumn{2}{|l|}{ yellow } & blue & blue \\
\hline $\begin{array}{l}\text { grain size, } \\
\text { shape }\end{array}$ & \multicolumn{2}{|l|}{$\begin{array}{l}\text { fine- to very coarse, often euhedral } \\
\text { oscillatory growth zoning }\end{array}$} & $\begin{array}{l}\text { fine- to coarse } \\
\text { relict oscillatory growth zoning }\end{array}$ & $\begin{array}{l}\text { fine- to medium } \\
\text { no zoning }\end{array}$ \\
\hline $\begin{array}{l}\text { zoning } \\
\text { textural } \\
\text { features }\end{array}$ & \multicolumn{2}{|l|}{ core; undulose } & replacement $\pm \mathrm{MoS}_{2}$, inner rim & outer rims, micro-fractures \\
\hline $\begin{array}{l}\mathrm{MoO}_{3} \\
\quad \text { (median) }\end{array}$ & \multicolumn{2}{|l|}{$1.18 \mathrm{wt} \%$} & $0.30 \mathrm{wt} \%$ & $<100-600$ ppm \\
\hline $\begin{array}{l}\text { interpretation } \\
\text { age }\end{array}$ & \multicolumn{2}{|l|}{$\begin{array}{l}\text { magmatic (?) hydrothermal } \\
\text { pre-Alpine, Variscan (?) }\end{array}$} & $\begin{array}{l}\text { metamorphic } \\
\text { unclear }\end{array}$ & metamorphic Alpine? \\
\hline \multicolumn{5}{|c|}{ FELBERTAL SCHEELITE DEPOSIT } \\
\hline & Stage 1 & Stage 2 & Stage 3 & Stage 4 \\
\hline $\begin{array}{l}\text { fluorescence } \\
\text { colour }\end{array}$ & pale yellow & yellow & blue & pale blue \\
\hline $\begin{array}{l}\text { grain size, } \\
\text { shape }\end{array}$ & $\begin{array}{l}<0.4 \mathrm{~mm} \text {, anhedral } \\
\text { delicate oscillatory growth zoning }\end{array}$ & $\begin{array}{l}\text { mm-cm, anhedral to euhedral } \\
\text { broad oscillatory growth }\end{array}$ & $\begin{array}{l}\text { mm; anhedral } \\
\text { irregular metam. Zoning }\end{array}$ & $\begin{array}{l}\mathrm{cm} \text {, euhedral } \\
\text { no zoning }\end{array}$ \\
\hline $\begin{array}{l}\text { zoning } \\
\text { textural } \\
\quad \text { features }\end{array}$ & $\begin{array}{l}\text { small porphyroclasts in foliated } \\
\text { ore }\end{array}$ & $\begin{array}{l}\text { zoning } \\
\text { large crystals; often deformed } \\
\text { and replaced }\end{array}$ & $\begin{array}{l}\text { replacement } \pm \mathrm{MoS}_{2} \text {, crack fillings, } \\
\text { re-crystallisation }\end{array}$ & $\begin{array}{l}\text { crystals in Alpine quartz } \\
\text { veins and clefts }\end{array}$ \\
\hline $\mathrm{MoO}_{3}$ & $\sim 1 \mathrm{wt} \%$ & $0.1-1.7 \mathrm{wt} \%$ & 100 ppm & $2-500 \mathrm{ppm}$ \\
\hline $\begin{array}{l}\text { interpretation, } \\
\text { age }\end{array}$ & $\begin{array}{l}\text { magmatic-hydrothermalVariscan } \\
335.5 \pm 4.6 \mathrm{Ma}\end{array}$ & $\begin{array}{l}\text { magmatic-hydrothermal } \\
\text { Variscan } \\
<335 \mathrm{Ma}\end{array}$ & $\begin{array}{l}\text { metamorphic } \\
\text { Variscan } \\
319 \pm 34 \mathrm{Ma}\end{array}$ & $\begin{array}{l}\text { metamorphic } \\
\text { Alpine } \\
31 \pm 4 \mathrm{Ma}\end{array}$ \\
\hline age reference & Raith et al. (2011) & Raith and Stein (2006) & Eichhorn et al. (1997) & \\
\hline
\end{tabular}




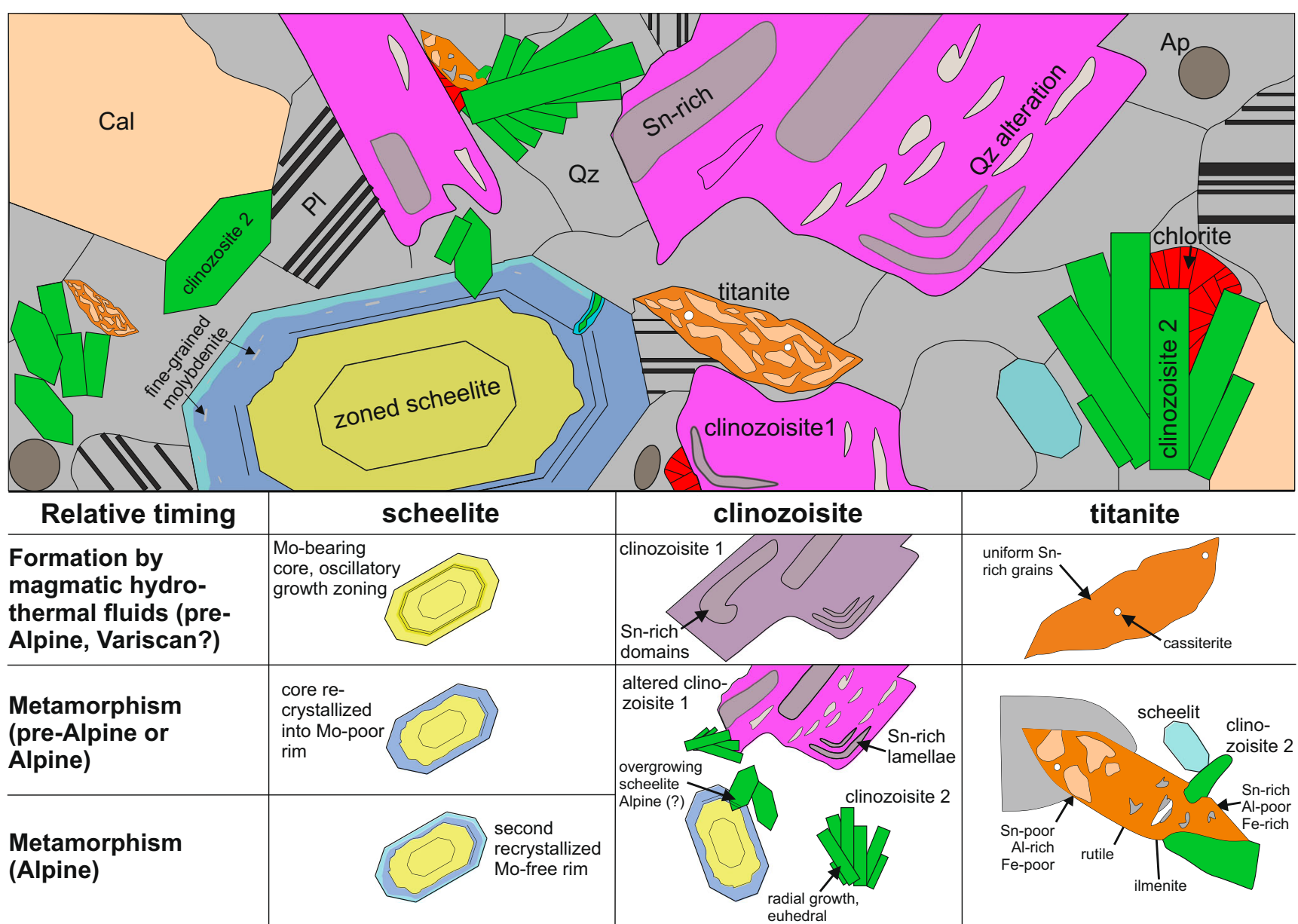

Fig. 12 Sketch summarising mineral associations with the three scheelite types in W-(Sn) skarn from Messelingscharte (top) and interpretative assignment to possible formation processes (bottom). The colour of scheelite has been chosen to resemble the fluorescence colour under UV light

and $\mathrm{Ti}^{4+}$. A maximum Sn-content of $3.00 \mathrm{wt} \% \mathrm{SnO}_{2}$ $(=0.094 \mathrm{apfu})$ was measured, which is the highest value ever recorded in the literature to the knowledge of the authors. A literature review revealed that there are only a few other occurrences of Sn-bearing clinozoisite/ epidote worldwide (Table 6). Sn-bearing clinozoisite/ epidote was reported from massive skarns and skarn veins in Cornwall, UK (Alderton and Jackson 1978; van Marcke de Lummen 1986), Cassiar district, British Columbia, Canada (Mulligan and Jambor 1968) and Baja, California (Myer 1965). In addition to Snbearing clinozoisite/epidote, garnet, pyroxene, amphibole and titanite are the other major Sn-carriers in these occurrences.

Tin-bearing calc-silicate bodies and veins were described from the St. Just aureole in the Land's End granite, Cornwall (Alderton and Jackson 1978). There, the host rocks are contact-metamorphosed basaltic plagioclase-amphibole hornfelses with interbedded banded amphibolites or banded garnet-magnetite calc-silicate rocks. The irregular-shaped discordant calc-silicate bodies and veins are composed of Ca-rich garnet, diopside, hornblende, epidote, \pm axinite, \pm tourmaline, \pm accessory calcite, quartz, titanite and sulphides.

Tin-bearing epidote was documented from the Chycornish Carn skarn vein composed of major epidote/clinozoisite, hornblende, axinite, tourmaline and accessory titanite etc. Cassiterite is absent in all these calc-silicate veins and the $\mathrm{Sn}$ carriers are silicates (Table 5). Alteration selvages with coarsegrained green amphibolite are developed at the contact to hornblende hornfels (Alderton and Jackson 1978). The calcsilicate veins are high in $\mathrm{Ca}, \mathrm{Sn}$ and $\mathrm{Be}$ and are crosscut by younger tin-copper lodes. The skarn veins were therefore interpreted as high-temperature $\left(\right.$ c. $\left.500{ }^{\circ} \mathrm{C}\right)$ metasomatic rocks predating $\mathrm{Cu}-\mathrm{Sn}$ mineralisation in the lodes. An external; i.e. granitic, source of elements like $\mathrm{Sn}$ and $\mathrm{Be}$ has been envisaged.

Sn-bearing clinozoisite with up to $2.84 \mathrm{wt} \% \mathrm{SnO}_{2}$ was described from The Crowns, also in the contact aureole of the Land's End granite. There, it is part of the retrograde skarn assemblage including stanniferous 
Table 6 Occurrences of Sn-bearing clinozoisite/epidote (updated, van Marcke de Lummen 1986). Information is given on geology, assemblage and maximum $\mathrm{SnO}_{2}$ content of clinozoisite/epidote. Concentrations of
$\mathrm{SnO}_{2}(\mathrm{wt} \%)$ of associated minerals are given in brackets. Mineral abbreviations according to Whitney and Evans (2010)

\begin{tabular}{|c|c|c|c|c|}
\hline locality & setting & $\begin{array}{l}\text { mineral } \\
\text { assemblage } \\
{[\text { vol\%] }}\end{array}$ & $\begin{array}{l}\max . \\
\mathrm{SnO}_{2} \\
{[\mathrm{wt} \%]}\end{array}$ & reference \\
\hline Messelingscharte, Tauern Window/AT & skarn vein & $\begin{array}{l}\text { Ttn 6.48, Czo 3.00, Chl, Qtz, Amp, Cal, } \\
\text { Sch }\end{array}$ & 3.00 & this study \\
\hline Baja California/MX & hydrothermal vein & not specified & 0.38 & Myer (1965) \\
\hline $\begin{array}{l}\text { Cassiar district, N British } \\
\text { Columbia/CA }\end{array}$ & $\begin{array}{l}\text { massive pyroxenite } \\
\text { skarn }\end{array}$ & Adr 0.9, Ep 0.8, Cpx, Amp 0.3, Qtz, Cal & 0.80 & Mulligan and Jambor (1968) \\
\hline $\begin{array}{l}\text { Chycornish Carn, Botallack, } \\
\text { Cornwall/UK }\end{array}$ & skarn vein & Ep, Ax, Amp 0.1, Tur & 0.16 & Alderton and Jackson (1978) \\
\hline The Crowns, Botallack, Cornwall/UK & $\begin{array}{l}\text { massive retrograde } \\
\text { skarn }\end{array}$ & $\begin{array}{l}\text { Ep 2.84, Amp 0.7, Ttn 7.0, Cst, Chl, } \\
\text { malayaite }\end{array}$ & 2.84 & $\begin{array}{l}\text { Van Marcke de Lummen } \\
\text { (1986) }\end{array}$ \\
\hline Shizhuyuan/CN & skarn & Gar 0.67, Di 0.14, Ep 0.37 & 0.37 & Chen et al. (1992) \\
\hline
\end{tabular}

epidote, cassiterite, amphibole, titanite/malayaite and chlorite and overprinting earlier grossular/andradite-rich skarn (van Marcke de Lummen 1986).

Stanniferous epidote has also been reported from Fe-rich pyroxenite skarns in the Cassiar district, British Columbia, Canada. These tin skarns belong to a mineralised belt with several Be, Sn, W and Mo occurrences that are spatially linked with granite batholiths in the Western Cordillera. The main constituents are Sn-bearing clinopyroxene, amphibole, epidote, garnet, calcite, quartz and accessory titanite; tin is incorporated in andradite, malayaite, epidote and amphibole (Table 6; Mulligan and Jambor 1968; Scribner et al. 2017).

Interestingly, at none of these localities scheelite has been reported as part of the $\mathrm{Sn}$-bearing assemblage. Cassiterite was only observed at The Crowns. Stannite is seldom reported from Sn skarns (e.g. Mt. Lindsay, Eadington and Kinealy 1983) and is also absent at Messelingscharte. Hence, in addition to clinozoisite/epidote, $\mathrm{Ca}$ garnet, amphibole and especially titanite and malayaite are the Sn carriers in these skarns.

All these reported skarns are connected to granite-related magmatic hydrothermal systems. It is therefore tempting to postulate a similar genesis for Messelingscharte although there are no geological indications for a contact metamorphic aureole at Messelingscharte. However, it must be kept in mind that the Cornish Sn-(W) granites with contact aureoles are post-orogenic whereas in the central Tauern Window preAlpine W-(Sn) mineralisation has been affected by the Alpine tectonics and metamorphism. Thus, the Alpine orogeny could have blurred many of the primary features.

\section{Stanniferous titanite in skarns}

Tin-bearing titanite from Messelingscharte $\left(\leq 6.48 \mathrm{wt} \% \mathrm{SnO}_{2}\right.$; $\leq 0.089$ apfu $\mathrm{Sn}$ ) is well comparable with titanite from tungsten and tin skarns regarding mineral assemblages and Sn content
(Table 7, e.g., Aleksandrov and Troneva 2007; Che et al. 2013; Plimer 1984; Xie et al. 2008).

For example, scheelite is associated with stanniferous titanite in a hedenbergite-quartz skarn vein at Písek, Czech Republic (Cempírek et al. 2008). They described Nband $\mathrm{Sn}$ bearing titanite showing a very similar type of patchy intra-grain texture such as the one at Messelingscharte (Fig. 11), which can be interpreted as a fluid-induced dissolution-re-precipitation texture. Moreover, titanite from scheelite-bearing skarns in British Columbia in general contains high but variable $\mathrm{Sn}, \mathrm{W}$ and $\mathrm{Nb}$ concentrations and occurs in common skarn assemblages with clinopyroxene, garnet, calcite, quartz, scheelite etc. (Che et al. 2013).

Sn-free titanite is a common accessory mineral of various non-skarn rocks in the Tauern Window. It was reported from high-pressure calcareous rocks in the Eclogite Zone of the Tauern Window (Franz and Spear 1985). There, titanite is high-Al $(\mathrm{x}(\mathrm{Al})=0.11-0.47)$ and F-rich $(\leq 5.4 \mathrm{wt} \% \mathrm{~F})$; i.e., $\mathrm{Al}$ contents overlap with Messelingscharte but F and Sn concentrations are clearly different to titanite from Messelingscharte. Two types of titanite were also reported from the Felbertal scheelite deposit. Titanites low in $\mathrm{F}$ and $\mathrm{Al}_{2} \mathrm{O}_{3}$ with distinct growth zoning are interpreted as magmatic, whereas those higher in $\mathrm{F}$ and $\mathrm{Al}_{2} \mathrm{O}_{3}$ and showing patchy replacement structures were interpreted as hydrothermal (Kozlik and Raith 2013). Both types do not incorporate $\mathrm{Sn}$ and are therefore different from titanite from Messelingscharte.

\section{Origin of skarn rocks}

\section{Processes of skarn formation}

Calc-silicate rocks, often collectively referred to as skarns, can form in different geologic environments by various processes (e.g., Meinert 1993). These can be subdivided broadly into 
Table 7 Selected occurrences of Sn-bearing titanite and malayaite (Mal). Information is given on geological setting, assemblage and maximum $\mathrm{SnO}_{2}$ content of titanite. Concentrations of $\mathrm{SnO}_{2}(\mathrm{wt} \%)$ of associated minerals are given in brackets. Mineral abbreviations according to Whitney and Evans (2010); Mal = malayite

\begin{tabular}{|c|c|c|c|c|}
\hline locality & $\begin{array}{l}\text { geological } \\
\text { setting }\end{array}$ & $\begin{array}{l}\text { assemblage } \\
{[\mathrm{vol} \%]}\end{array}$ & $\begin{array}{l}\max . \mathrm{SnO}_{2} \\
{[\mathrm{wt} \%]}\end{array}$ & reference \\
\hline Messelingscharte, Tauern Window/AT & skarn vein & Ttn 6.48, Czo 3.0, Amp, Sch, Cal & 6.48 & this study \\
\hline The Crowns, Botallack, Cornwall/UK & $\begin{array}{l}\text { massive retrograde } \\
\text { skarn }\end{array}$ & $\begin{array}{l}\text { Ttn 7.0, Czo 2.84, Amp 0.7, Cst, } \\
\text { Chl, Mal }\end{array}$ & 7.0 & $\begin{array}{l}\text { Van Marcke de Lummen } \\
\text { (1986) }\end{array}$ \\
\hline Yukon and British Columbia/CA & skarn & Cpx, Grt, Sch, Qz, Clc, Ttn 1.0 & 1.0 & Che et al. (2013) \\
\hline $\begin{array}{l}\text { Ash Mountain skarn, Tuya Range, British } \\
\text { Columbia/CA }\end{array}$ & skarn & Grs 0.05, Adr 1.10, Mal, Cpx, Ves & malayaite $(>50 \%)$ & Scribner et al. (2017) \\
\hline Bol'shoi Kan'on/RU & skarn & $\begin{array}{l}\text { Ttn 8.85, Ves, Grs 1.4, Ax 0.31, Cpx } \\
\text { 0.1, Mal }\end{array}$ & $\begin{array}{l}\text { 8.85; malayaite } \\
\quad(>45 \%)\end{array}$ & $\begin{array}{l}\text { Aleksandrov and Troneva } \\
\text { (2007) }\end{array}$ \\
\hline Pisek/CZ & skarn & Cpx, Grt, Phl, Cal, Ep/Czo, Sch & 0.41 & Cempírek et al. (2008) \\
\hline Doradilla, New South Wales/AU & skarn & Grs 3.5, Cpx 0.11, Mal, Ttn, Cal & $>50 \%$ (malayaite) & Plimer (1984) \\
\hline
\end{tabular}

isochemical (except for devolatilisation) and allochemical ones.

Isochemical formation of calc-silicate rocks (calc-silicate hornfels) is controlled by internal fluid buffering and is typical for regional and contact metamorphism of impure carbonate rocks (e.g., Central Alps, Trommsdorff 1966). Local fluid exchange at the contacts between shales and limestones and differences in the chemical potential of contrasting lithologies cause formation of reaction skarns, small-scale calc-silicate bands or zoned nodules (e.g., Joesten 1974; Thompson 1975). These can show striking similarity to infiltration skarns (Einaudi et al. 1981).

This ambiguity is especially true for scheelite-bearing calcsilicate rocks. In addition to magmatic tungsten skarns that are the main resource of tungsten (Meinert et al. 2005) there are smaller sub-economic tungsten deposits hosted in regional metamorphic calc-silicate rocks unrelated to granites. They were classified as stratiform/strata-bound scheelite deposits with $\mathrm{W}$ concentrated by exhalative-hydrothermal or evaporitic fluids (Broken Hill Block, NSW, Australia, Plimer 1980; Plimer 1994; Austroalpine Crystalline Complex, Austria, Raith 1991; Bindal area, Norway, Skaarup 1974); often they are associated with tourmalinites (Plimer 1987; Raith 1988). The calc-silicate rocks at Messelingscharte are not hosted by marble or other calcareous metasediments but by metabasites; tourmalinites are missing. The skarn-like rock forms irregular pods but not laterally continuous two-dimensional stratiform or strata-bound ore bodies. There are no metasomatic reaction zones between the skarn and host rocks. Thus, syngenetic/ syndiagenetic models for $\mathrm{W}$ enrichment by exhalative or evaporitic ore fluids are excluded for Messelingscharte.

Another type of calc-silicate rocks are rodingites that are known from the Tauern Window (Dietrich et al. 1986; Koller and Richter 1983). These are metasomatic rocks composed of (hydro)grossular, clinopyroxene, vesuvianite etc. formed by interaction of fluids with meta-ultramafic rocks and metabasites during serpentinisation and/or regional metamorphism (Barriga and Fyfe 1983). In the Tauern Window, they were interpreted as a product of metamorphic fluids interacting with metabasites during Variscan and Alpine regional metamorphism (Koller and Richter 1983). Regarding the geology there are similarities of Messelingscharte skarn rocks to the rodingites although the calc-silicate mineralogy is markedly different; i.e., grossular + clinopyroxene vs. predominance of clinozoisite. Moreover, blackwall zones common in rodingites are not developed at Messelingscharte.

A third type of calc-silicate rock known in the Tauern Window is metamorphic zoisite and clinozoisite segregations occurring in metabasites of the Basal Amphibolite unit (Brunsmann et al. 2000). These are comparable to Messelingscharte in regard to the geological setting and mineralogy. But these metamorphic segregations are clearly distinguished by their texture and trace element composition; e.g., they lack W, Sn, Be and show totally different REE patterns (e.g. very high $(\mathrm{La} / \mathrm{Yb})_{\mathrm{N}}$, weakly positive Eu anomaly; see Fig. 5 in Brunsmann et al. 2000). Skarn rocks of Messelingscharte are characterised by pronounced positive Eu-anomalies and low LREE/HREE values $\left((\mathrm{La} / \mathrm{Yb})_{\mathrm{N}} \sim 0.8\right)$.

The vast majority of $\mathrm{W}$ mineralised calc-silicate rocks are magmatic tungsten skarns. They form by infiltration and reaction of external fluids predominantly of magmatichydrothermal origin with Ca-rich lithologies. Tungsten and tin skarns are spatially connected with evolved granites commonly forming proximal calcic exoskarns but can also form more distally along faults and major shear zones. Magmatic tungsten skarns such as Cantung, Canada, or King Island, Australia, are typically associated with evolved granites (Meinert 1993). Some Sn-W-F-Be skarns show elevated concentrations of $\mathrm{Be}$ and $\mathrm{F}$ with magnetite and fluorite becoming important skarn minerals and $\mathrm{Sn}$ being incorporated in 
silicates (titanite, garnet, amphibole, ilvaite) during the later skarn stages (Mt. Lindsey, Australia, Kwak 1983; Moina, Australia, Kwak and Askins 1981). The characteristic hightemperature $\left(>700^{\circ} \mathrm{C}\right)$ mineralogy of tungsten skarns is garnet + clinopyroxene \pm calcian amphibole \pm wollastonite etc. Retrograde lower temperature (c. $300-400{ }^{\circ} \mathrm{C}$ ) skarn assemblages overprinting the early one include clinozoisite/epidote, chlorite, amphibole, calcite etc. (Meinert 1992, 1993; Meinert et al. 2005).

Thus, the mineral assemblage of the clinozoisitedominated skarn at Messelingscharte is similar to lower temperature skarn assemblages. Stanniferous clinozoisite and titanite and Mo-bearing scheelite are the main minerals of the pre-metamorphic mineral assemblage. Reported occurrences of stanniferous epidote/clinozoisite and stanniferous titanite are all interpreted as late stage (?) magmatic infiltration skarns (Tables 6 and 7). The lack of the garnet-clinopyroxene high-temperature assemblages can be explained with the distal position of skarn formation which is further corroborated by the lack of a contact aureole and nearby granite intrusion. Distal Sn-W skarns with similar mineralogy have been reported from Sangdong, South Korea, and Gejiu district, China (Kwak 1987) and the distal strata-bound scheelite skarns in the Riba de Alva Mine, Northeastern Portugal (Gaspar and Inverno 2000).

The regional geological setting of Messelingscharte also supports the model of distal skarn formation. The worldclass Felbertal scheelite deposit is located only about $8 \mathrm{~km}$ north of Messelingscharte. Recent studies confirmed the Variscan age of this deposit and the genetic link with c. 335340 Ma evolved granites ("K1-K3 orthogneiss") in the deposit (Kozlik and Raith 2017; Kozlik et al. 2016). Regarding its chemical composition this orthogneiss is best grouped with the Felbertal augengneiss, which is of the same age but is less differentiated.

Contrary to this, the Granatspitz gneiss dated at $314 \pm$ $18 \mathrm{Ma}$ and exposed to the east of Messelingscharte, is clearly younger and derived from different more juvenile crustal source rocks (Kozlik and Raith 2017). Hence, although the Messelingscharte prospect is located at the western periphery of the Granatspitz gneiss dome (Fig. 1) granites of the Felbertal augengneiss "clan" must be regarded as the more likely source of $\mathrm{W}$ mineralisation. The nearest outcrops of these orthogneisses are located about $0.5 \mathrm{~km}$ to the west of the main scheelite showings (Fig. 1). Today the primary contacts between Basal Amphibolite and Felbertauern augengneiss are, however, tectonically strongly reworked.

\section{Fluid composition and chemical changes during skarn formation}

Interaction of hydrothermal fluids with the amphibolite host rock is a key process in explaining $\mathrm{W}$-(Sn) skarn mineralisation at Messelingscharte. In the following, we have tried to constrain the fluid composition and the chemical changes during skarn formation.

The incorporation of $\mathrm{Sn}$ in silicates and lack of cassiterite put some constraints on the fluid composition of the hydrothermal fluids. Formation of Sn-bearing clinozoisite and suppression of cassiterite crystallisation in skarns is controlled by the $\mathrm{XCO}_{2}\left(=\mathrm{CO}_{2} /\left(\mathrm{CO}_{2}+\mathrm{H}_{2} \mathrm{O}\right)\right)$ and the $\mathrm{pH}$ of the fluid phase; i.e. cassiterite is known to be stable at higher $\mathrm{XCO}_{2}$ values and acidic (e.g. HF-rich) conditions (Burt 1978). This is consistent with the formation of a clinozoisite skarn because low $\mathrm{XCO}_{2}$ values are also required for forming epidote/clinozoisite (Plimer 1993) as well as malayaite in skarns (Burt 1978).

The studied skarn rocks are strongly enriched in calcium (average 15.02 wt\% CaO in skarn; 9.83 wt\% CaO in amphibolites). The trace elements $\mathrm{Eu}^{2+}$ and $\mathrm{Sr}^{2+}$ are enriched together with $\mathrm{Ca}^{2+}$ (Fig. 5a,b). The source of these elements likely are the amphibolite host rocks affected by the infiltrating hydrothermal fluid. Breakdown of plagioclase in the metabasite during interaction with fluid would liberate these elements, which are then incorporated in the skarn in calc-silicate minerals and in scheelite.

A puzzling feature of the studied skarn is the depletion in high field strength elements like $\mathrm{Zr}$, Hf and Ti relative to the amphibolite host rocks (Figs. 5a and 6). Similarly, the REE, except Eu, also show limited mobility. The strong negative spikes at $\mathrm{Zr}$, Hf, and $\mathrm{Ti}$ in the spidergrams can be explained in two ways. (1) This pattern reflects their low mobility in the hydrothermal fluid; i.e., these HFS elements remained more or less fixed in the host rock during $\mathrm{Ca}$ metasomatism; e.g., $\mathrm{Zr}$ and $\mathrm{Hf}$ were fixed in zircon, and $\mathrm{Ti}$ bound in titanium oxides. (2) Alternatively, these HFS elements could be preferentially removed. Solubility of rutile in hydrothermal fluids is strongly enhanced with increasing temperature and pressure (Ayers and Watson 1993) and presence of $\mathrm{Cl}$ and/or $\mathrm{F}$ in the fluids enhance the mobility of HFS elements (Jiang et al. 2005); in particular the presence of $\mathrm{F}$ in high-temperature metamorphic fluids has dramatic effects on the solubility of rutile (Rapp et al. 2010). The elevated F-content in titanite suggests that fluorine was present in the mineralising skarn system eventually facilitating mobility of HFS elements. At present it is unclear which of the two processes is applicable to Messelingscharte.

The hydrothermal fluid definitely transported the metals W, Sn and Be, elements that are clearly enriched in the skarn compared to the host rock (Fig. 6). We regard this element suite as a fingerprint of the granitic provenance of the fluid because $\mathrm{W}, \mathrm{Sn}$ and Be are typically enriched in highly fractionated granitic melts. As stated above, fluorine is part of this element spectrum too as suggested by the mineral chemical composition 
of stanniferous titanite. Higher fluorine contents have also been reported from the Felbertal scheelite deposit (Kozlik and Raith 2013; Kozlik and Raith 2017) although they are much lower than those of highly fractionated rare metal granites and pegmatites associated with Sn, W, Li, Ta mineralisation (e.g., Badanina et al. 2006; Förster et al. 1999), or of Sn, W, Be, F skarn and greisen deposits (Aleksandrov 2010; Audetat et al. 2000; Kwak and Askins 1981). In summary, the trace element chemistry strongly supports the model of a granitic provenance of the mineralising fluids.

\section{Conclusions}

(1) Mineralisation styles at Messelingscharte tungsten exploration target include an unusual stanniferous clinozoisite-scheelite skarn hosted in metabasites, a deformed quartz stockwork and mylonitic quartz-scheelite veins. Scheelite and the skarn minerals clinozoisite and titanite record a polyphase formation and regional metamorphic overprint. The different types of scheelite allow correlation with the nearby Felbertal scheelite deposit.

(2) Tin is exclusively incorporated in the lattice of clinozoisite and titanite. Concentrations of $3.00 \mathrm{wt} \%$ $\mathrm{SnO}_{2}$ in clinozoisite are the highest values recorded for this mineral so far. Substitution of $(\mathrm{Al}, \mathrm{Fe})^{3+}$ by $(\mathrm{Sn}, \mathrm{Ti})^{4+}$ in clinozoisite is coupled with incorporation of $\mathrm{Fe}^{2+}$.

(3) The W-(Sn) skarn formed by reaction of hydrothermal fluids with the amphibolite host rock. The fluids transported elevated concentrations of the granitophile elements W, Sn, Be and F. The granitophile element suite supports the interpretation that Messelingscharte is an unusual distal W-(Sn) skarn, although the granitic source of the magmatic hydrothermal fluids is still unidentified.

(4) In the regional context, the $\mathrm{W}$-(Sn) mineralisation at Messelingscharte can be seen as part of a larger W mineralising magmatic system related to Early Carboniferous granitic intrusions in the central Tauern Window that also resulted in formation of the worldclass Felbertal scheelite deposit.

Acknowledgements Wolfram Bergbau und Hütten AG is thanked for initiating this project and for providing financial and logistic support. Maik Zimmermann and Federica Zaccarini, Chair of Resource Mineralogy, Montanuniversität Leoben, are thanked for sample preparation and help with the EPMA analyses. The first author also wants to thank Frank Melcher, Katharina Schneider, Timotheus Steiner, Martin Stern and Werner Ordosch who joined the field work and assisted with UV-lamping during field work in summer 2016. Moreover, the team of the St. Pöltener Hütte was very supportive to secure safe field work in the high mountains.

Funding Information Open access funding provided by Montanuniversität Leoben.
Open Access This article is distributed under the terms of the Creative Commons Attribution 4.0 International License (http:// creativecommons.org/licenses/by/4.0/), which permits unrestricted use, distribution, and reproduction in any medium, provided you give appropriate credit to the original author(s) and the source, provide a link to the Creative Commons license, and indicate if changes were made.

\section{References}

Alderton DHM, Jackson NJ (1978) Discordant calc-silicate bodies from the St. Just aureole, Cornwall. Mineral Mag 42:427-434

Aleksandrov SM (2010) Skarn-greisen deposits of the Lost River and Mount Ear ore field, Seward Peninsula, Alaska, United States. Geochem Int 48:1220-1236

Aleksandrov SM, Troneva MA (2007) Composition, Mineral assemblages, and genesis of titanite and malayaite in skarns. Geochem Int 45:1012-1024

Armbruster T, Bonazzi P, Akasaka M, Bermanec V, Chopin C, Giere R, HeussßAssbicherl S, Liebscher A, Menchetti S, Pan Z, Pasero M (2006) Recommended nomenclature of epidote-group minerals. Eur J Mineral 18:551-567

Audédat A, Günther D, Heinrich CA (2000) Magmatic-hydrothermal evolution in a fractionating granite: A microchemical study of the Sn-W-F-mineralized Mole Granite (Australia). Geochim Cosmochim Acta 64:3373-3393

Ayers JC, Watson EB (1993) Rutile solubility and mobility in supercritical aqueous fluids. Contrib Mineral Petrol 114:321-330

Badanina EV, Trumbull RB, Dulski P, Wiedenbeck M, Veksler IV, Syritso LF (2006) The behaviour of rare-earth and lithophile trace elements in rare-metal granites: a study of fluorite, melt inclusions and host rocks from the Khangilay Complex, Transbaikalia, Russia. Can Mineral 44:667-692

Barriga F, Fyfe WS (1983) Development of rodingite in basaltic rocks in serpentinites, East Liguria, Italy. Contrib Mineral Petrol 84:146-151

Bevins RE, Kokelaar BP, Dunkley PN (1984) Petrology and geochemistry of lower to middle Ordovician igneous rocks in Wales: a volcanic arc to marginal basin transition. Proc Geol Assoc 95:337-347

Boynton WV (1984) Geochemistry of the rare earth elements: meteorite studies. In: Henderson P (ed) Rare earth element geochemistry. Elsevier, Amsterdam, pp 63-114. https://doi.org/10.1016/B978-0444-42148-7.50008-3

Brunsmann A, Franz G, Erzinger J, Landwehr D (2000) Zoisite- and clinozoisite-segregations in metabasites (Tauern Window, Austria) as evidence for high-pressure fluid-rock interaction. J Metamorph Geol 18:1-21

Burt DM (1978) Tin silicate-borate-oxide equilibria in skarns and greisens-the system $\mathrm{CaO}-\mathrm{SnO}_{2}-\mathrm{SiO}_{2}-\mathrm{H}_{2} \mathrm{O}-\mathrm{B}_{2} \mathrm{O}_{3}-\mathrm{CO}_{2}-\mathrm{F}_{2} \mathrm{O}_{-1}$. Econ Geol 73:269-282

Cempírek J, Houzar S, Novák M (2008) Complexly zoned niobian titanite from hedenbergite skarn at Písek, Czech Republic, constrained by substitutions $\mathrm{Al}(\mathrm{Nb}, \mathrm{Ta}) \mathrm{Ti}_{-2}, \mathrm{Al}(\mathrm{F}, \mathrm{OH})(\mathrm{TiO})_{-1}$ and $\mathrm{SnTi}_{-1}$. Mineral Mag 72:1293-1305

Che XD, Linnen RL, Wang RH, Groat LA, Brand AA (2013) Distribution of trace and rare earth elements in titanite from tungsten and molybdenum deposits in Yukon and British Columbia, Canada. Can Mineral 51:415-438

Chen J, Halls C, Stanley CJ (1992) Tin-bearing skarns of South China: Geological setting and mineralogy. Ore Geol Rev 7:225-248

Corfu F, Hanchar JM, Hoskin PW, Kinny P (2003) Atlas of zircon textures. Rev Mineral Geochem 51:431-435 
Dietrich H, Koller F, Richter W, Kiesl W (1986) Petrology und Geochemie des Rodingitvorkommens vom Islitzfall (Dorfertal, Hohe Tauern). Schweiz Mineral Petrogr Mitt 66:163-192

Droop GTR (1987) A general equation for estimating Fe3+ concentrations in ferromagnesian silicates and oxides from microprobe analyses, using stoichiometric criteria. Mineral Mag 51:431-435

Eadington PF, Kinealy K (1983) Some aspects of the hydrothermal reactions of tin during skarn formation. J Geol Soc Austral 30:461-471

Eichhorn R, Höll R, Jagoutz E, Schärer U (1997) Dating scheelite stages: A strontium, neodymium, lead approach from the Felbertal tungsten deposit, Central Alps, Austria. Geochim Cosmochim Acta 61:50055022

Eichhorn R, Loth G, Höll R, Finger F, Schermaier A, Kennedy A (2000) Multistage Variscan magmatism in the central Tauern Window (Austria) unveiled by U/Pb SHRIMP zircon data. Contrib Mineral Petrol 139:418-435

Eichhorn R, Loth G, Kennedy A (2001) Unraveling the pre-Variscan evolution of the Habach terrane (Tauern Window, Austria) by U$\mathrm{Pb}$ SHRIMP zircon data. Contrib Mineral Petrol 142:147-162

Eichhorn R, Schärer U, Höll R (1995) Age and evolution of scheelitehosting rocks in the Felbertal deposit (Eastern Alps): U-Pb geochronology of zircon and titanite. Contrib Mineral Petrol 119:377-386

Einaudi MT, Meinert LD, Newberry RJ (1981) A special issue devoted to skarn deposits. Introduction - terminology, classification, and composition of skarn deposits. Econ Geol 77:317-391

Förster HJ, Tischendorf G, Trumbull RB, Gottesmann B (1999) Latecollisional granites in the Variscan Erzgebirge, Germany. J Petrol 40:1613-1645

Frank W (1969) Geologie der Glocknergruppe. Wiss Alpenvereinshefte 21:95-113

Franz G, Spear FS (1985) Aluminous titanite (sphene) from the Eclogite Zone, south- central Tauern Window, Austria. Chem Geol 50:33-46

Frank W, Höck V, Miller C (1987) Metamorphic and tectonic history of the central Tauern Window. In: Flügel HW, Faupl P (eds) Geodynamics of the Eastern Alps. Deuticke, Wien, pp 34-54

Frasl G (1958) Zur Seriengliederung der Schieferhülle in den Mittleren Hohen Tauern. Jb Geol B-A 101:323-472

Frei D, Liebscher A, Franz G, Dulski P (2004) Trace element geochemistry of epidote minerals. Rev Mineral Geochem 55:553-605

Frisch W (1977) Der alpidische Internbau der Venedigerdecke im westlichen Tauernfenster. Neu Jb Geol Paläont Mh 11:675-696

Frisch W, Raab D (1987) Early Paleozoic back-arc and island-arc settings in greenstone sequences of the central Tauern Window (Eastern Alps). Jb Geol B-A 129:545-566

Fuchs G (1959) Über ein pyroklastisches Gestein aus der Granatspitzhülle (Hohe Tauern). Verh Geol B-A 1959:145-148

Gaspar LM, Inverno CMC (2000) Mineralogy and metasomatic evolution of distal strata-bound scheelite skarns in the Riba de Alva Mine, northeastern Portugal. Econ Geol 95:1259-1275

Groat LA, Carter RT, Hawthorn FC (1985) Tantalian niobian titanite from the Irgon claim, southeastern Manitoba. Can Mineral 23(569):571

Higgins JB, Ribbe PH (1976) The crystal chemsitry and space groups of natural and synthetic titanites. Amer Miner 61:878-888

Höck V (1993) The Habach-Formation and the Zentralgneis - A key in understanding the Palaeozoic evolution of the Tauern Window (Eastern Alps). In: Raumer JF, Neubauer F (eds) Pre-Mesozoic geology in the Alps. Springer, Berlin Heidelberg, pp 361-374. https:// doi.org/10.1007/978-3-642-84640-3 22

Hoernes S, Friedrichsen H (1974) Oxygen isotope studies on metamorphic rocks of the Western Tauern area (Austria). Schweiz Mineral Petrogr Mitt 54:769-788

Höll R (1975) Die Scheelitlagerstätte Felbertal und der Vergleich mit anderen Scheelitvorkommen in den Ostalpen. Abhandlungen Bayrische Akademie der Wissenschaften. Mathematischnaturwissenschaftliche Klasse München 157A:1-114
Höll R, Eichhorn R (2000) Tungsten mineralization and metamorphic remobilization in the Felbertal scheelite deposit, Central Alps, Austria. Rev Econ Geol 11:233-264

Hollabaugh CL, Rosenberg PE (1983) Substitution of Ti for Si in titanite and new end-member cell dimensions for titanite. Amer Miner 68: $177-180$

Jiang SY, Wang RC, Xu XS, Zhao KD (2005) Mobility of high field strength elements (HFSE) in magmatic-, metamorphic-, and submarine-hydrothermal systems. Phys Chem Earth 30:1020-1029

Joesten R (1974) Local equilibrium and metasomatic growth of zoned calc-silicate nodules from a contact aureole, Christmas Mounts, Big Bend Region, Texas. Amer J Sci 274:876-901

Kebede T, Klötzli U, Kosler J, Skiöld T (2005) Understanding the preVariscan and Variscan basement components of the central Tauern Window, Eastern Alps (Austria): constraints from single zircon U$\mathrm{Pb}$ geochronology. Int J Earth Sci 94:336-353

Koller F, Richter W (1983) Die Metrodingite der Habachformation, Hohe Tauern (Österreich). Tschermaks Mineral Petrogr Mitt 33:49-66

Kozlik M, Raith JG (2013) Hydrothermally induced fluorine enrichment in metagranitoids of the Felbertal scheelite deposit (Austria). In: Jonnson E (ed) Mineral deposit research for a high-tech world. Proceedings of the 12th Biennial SGA Meeting. Society for Geology Applied to Mineral Deposits, Uppsala, pp 1271-1274

Kozlik M, Raith JG (2017) Variscan metagranitoids in the central Tauern Window (Eastern Alps, Austria) and their role in the formation of the Felbertal scheelite deposit. Lithos 278:303-320

Kozlik M, Raith JG, Gerdes A (2016) U-Pb, Lu-Hf and trace element characteristics of zircon from the Felbertal scheelite deposit (Austria): New constraints on timing and source of $\mathrm{W}$ mineralization. Chem Geol 421:112-126

Kraiger H (1989) Die Habachformation - ein Produkt ozeanischer und kontinentaler Kruste. Mitt Österr Geol Gesell 81:47-64

Kunz M, Xirouchakis D, Wang Y, Parise JB, Lindsley DH (1997) Structural investigations along the join $\mathrm{CaTiOSiO}_{4}-\mathrm{CaSnOSiO}_{4}$. Schweiz Mineral Petrogr Mitt 77:1-11

Kwak TAP (1983) The geology and geochemistry of the zoned, Sn-W-FBe skarns at Mt. Lindsay, Tasmania, Australia. Econ Geol 78:1440 1465

Kwak TAP (1987) W-Sn skarn deposits: and related metamorphic skarns and granitoids. Developments in Economic Geology 24. Elsevier, Amsterdam

Kwak TAP, Askins PW (1981) Geology and genesis of the F-Sn-W(-BeZn) skarn (wrigglite) at Moina, Tasmania. Econ Geol 76:439-467

Kwak TA, Tan HT (1981) The geochemistry of zoning in skarn minerals at the King Island (Dolphin) Mine. Econ Geol 76:468-497

Lammerer B, Weger M (1998) Footwall uplift in an orogenic wedge; the Tauern Window in the Eastern Alps of Europe. In: Jolivet L, Gapais $\mathrm{D}$ (eds) Extensional tectonics and exhumation of metamorphic rocks in mountain belts. Elsevier, Amsterdam, pp 213-230. https://doi. org/10.2113/gsecongeo.76.2.468

Meinert LD (1992) Skarns and skarn deposits. Gesci Can 19:145-162

Meinert LD (1993) Igneous petrogenesis and skarn deposits. In: Kirkham RV, Sinclair WD, Thorpe RI, Duke JM (eds) Mineral deposit modeling. Geological Association of Canada, Special Paper, pp 569-583

Meinert LD, Dipple GM, Nicolescu S (2005) World skarn deposits. In: Hedenquist JW, Thompson JFH, Goldfarb RJ, Richards JP (eds) Economic Geology One Hundreth Anniversary Volume 19052005. Society of Economic Geologists, Littleton, pp 299-336. https://doi.org/10.5382/AV100.11

Mulligan R, Jambor JL (1968) Tin-bearing silicates from skarn in the Cassiar district, northern British Columbia. Can Mineral 9:358-370

Myer GH (1965) X-ray determinative curve for epidote. Amer J Sci 263: $78-86$

Oberti R, Smith DC, Rossi G, Caucia F (1991) The crystal chemistry of high-aluminum titanites. Eur J Mineral 3:777-792 
Ordosch A (2017) W-Sn mineralisation in calc-silicate rocks of the Basal Amphibolite unit at Messelingscharte (Felbertauern area, Austria). Diploma thesis, Montanuniversität Leoben, pp 188

Pearce JA, Alabaster T, Shelton AW, Searle MP (1981) The Oman ophiolite as a Creaceous arc-basin complex: evidence and implications. Philos Trans Roy Soc London A 300:399-317

Pestal G, Hejl E, Braunstingl R, Schuster R (2009) Erläuterungen Geologische Karte von Salzburg 1:200.000. Land Salzburg \& Geol B-A, Salzburg

Plimer IR (1980) Exhalative Sn and W deposits associated with mafic volcanism as precursors to $\mathrm{Sn}$ and $\mathrm{W}$ deposits associated with granites. Mineral Deposita 15:275-289

Plimer IR (1984) Malayaite and tin-bearing silicates from a skarn at Doradilla via Bourke, New South Wales. Aust J Earth Sci 31:147153

Plimer IR (1987) The association of tourmalinite with stratiform scheelite deposits. Mineral Deposita 22:282-291

Plimer IR (1993) Epidote and ore deposits. Abh Geol B-A 49:27-32

Plimer IR (1994) Strata-bound scheelite in meta-evaporites, Broken Hill, Australia. Econ Geol 89:423-437

Raith JG (1988) Tourmaline rocks associated with stratabound scheelite mineralization in the Austroalpine crystalline complex, Austria. Mineral Petrol 39:265-288

Raith JG (1991) Stratabound tungsten mineralization in regional metamorphic calc-silicate rocks from the Austroalpine Crystalline Complex. Austria Miner Deposita 26:72-80

Raith JG, Gerdes A, Cornell DH (2011) In situ U-Pb dating of scheelite: Constraints on the age and genesis of the Felbertal tungsten deposit. Mineral Mag 75:1690

Raith JG, Schmidt S (2010) Tungsten deposit Felbertal, Salzburg, Austria. Acta Mineralogica-Petrographica, Field Guide Series 3:124

Raith JG, Schmidt S, Aupers K (2018) Field Trip Pre-EX 5. Tungsten deposit Felbertal, Salzburg, Austria Berichte der Geologischen Bundesanstalt 126:7-46

Raith JG, Stein HJ (2006) Variscan ore formation and metamorphism at the Felbertal scheelite deposit (Austria): constraining tungsten mineralisation from $\mathrm{Re}-\mathrm{Os}$ dating of molybdenite. Contrib Mineral Petrol 152:505-521

Rapp JF, Klemme S, Butler IB, Harley SL (2010) Extremely high solubility of rutile in chloride and fluoride-bearing metamorphic fluids: An experimental investigation. Geology 38:323-326

Ribbe PH (1982) Titanite. Rev Mineral Geochem 5:137-154

Sahama TG (1946) On the chemistry of the mineral titanite. Bulletin de la Commission Geologique de Finlande 138:88-120
Schmid SM, Fügenschuh B, Kissling E, Schuster R (2004) Tectonic map and overall architecture of the Alpine orogeny. Eclogae Geol Helv 97:93-117

Schmid SM, Scharf A, Handy M, Rosenberg C (2013) The Tauern Window (Eastern Alps, Austria): a new tectonic map, with crosssections and a tectonometamorphic synthesis. Swiss J Geosci 106: $1-32$

Schuster R, Pestal G, Reitner JM, Ahl A, Arndt R, Heinrich M, Hejl E, Hobiger G, Jochum B, Kollmann W, Motschka K, Schedl A, Slapansky P, Winkler E (2006) Erläuterungen zu Blatt 182 Spittal an der Drau. Geologische Bundesanstalt, Wien

Scribner ED, Groat LA, Cempírek J (2017) Mineralogy of the Ash Mountain Sn-Bearing Skarn, Tuya Range, Northern British Columbia, Canada. Can Mineral 55:333-347

Skaarup P (1974) Strata-bound scheelite mineralisation in skarns and gneisses from the Bindal area, Northern Norway. Mineral Deposita 9:299-308

Takenouchi S (1971) Hydrothermal synthesis and consideration of the genesis of malayaite. Mineral Deposita 6:335-347

Thompson AB (1975) Calc-silicate diffusion zones between marble and pelitic schist. J Petrol 16:314-346

Trommsdorff V (1966) Progressive Metamorphose kieseliger Karbonatgesteine in den Zentralalpen zwischen Bernina und Simplon. Schweiz Mineral Petrogr Mitt 46:431-460

Ulmer P (1993) TEST Norm-program for cation and oxygen mineral norms. Computer Library IMP-ETH, Zürich

van Marcke de Lummen G (1986) Tin-bearing epidote from skarn in the Land's End aureole, Cornwall, England. Can Mineral 24:411-415

Vavra G, Frisch W (1989) Pre-Variscan back-arc and island-arc magmatism in the Tauern Window (Eastern Alps). Tectonophysics 169:271-280

von Quadt A (1992) U-Pb zircon and Sm-Nd geochronology of mafic and ultramafic rocks from the central part of the Tauern Window (Eastern Alps). Contrib Mineral Petrol 110:57-67

Whitney DL, Evans BW (2010) Abbreviations for names of rock-forming minerals. Amer Miner 95:185-187

Xie L, Wang R, Chen J, Zhu J, Zhang W, Wang D, Yu A (2008) Primary Sn-rich titianite in the Qitianling granite, Hunan Province, southern China: An important type of tin-bearing mineral and its implications for tin exploration. Chin Sci Bull 54:798-805

Publisher's note Springer Nature remains neutral with regard to jurisdictional claims in published maps and institutional affiliations. 